\title{
Constraints on the rheology of the lower crust in a strike-slip plate boundary: evidence from the San Quintín xenoliths, Baja California, Mexico
}

\author{
Thomas van der Werf ${ }^{1}$, Vasileios Chatzaras ${ }^{1,2}$, Leo Marcel Kriegsman ${ }^{1,3}$, Andreas Kronenberg ${ }^{4}$, Basil Tikoff ${ }^{2}$, and \\ Martyn R. Drury ${ }^{1}$ \\ ${ }^{1}$ Department of Earth Sciences, Utrecht University, Utrecht, the Netherlands \\ ${ }^{2}$ Department of Geoscience, University of Wisconsin-Madison, Madison, Wisconsin, USA \\ ${ }^{3}$ Department of Research \& Education, Naturalis Biodiversity Center, Leiden, the Netherlands \\ ${ }^{4}$ Department of Geology and Geophysics, Texas A\&M University, College Station, Texas, USA
}

Correspondence: Vasileios Chatzaras (v.chatzaras@uu.nl)

Received: 30 April 2017 - Discussion started: 11 May 2017

Revised: 21 September 2017 - Accepted: 20 October 2017 - Published: 21 December 2017

\begin{abstract}
The rheology of lower crust and its transient behavior in active strike-slip plate boundaries remain poorly understood. To address this issue, we analyzed a suite of granulite and lherzolite xenoliths from the upper Pleistocene-Holocene San Quintín volcanic field of northern Baja California, Mexico. The San Quintín volcanic field is located $20 \mathrm{~km}$ east of the Baja California shear zone, which accommodates the relative movement between the Pacific plate and Baja California microplate. The development of a strong foliation in both the mafic granulites and lherzolites, suggests that a lithospheric-scale shear zone exists beneath the San Quintín volcanic field. Combining microstructural observations, geothermometry, and phase equilibria modeling, we estimated that crystal-plastic deformation took place at temperatures of $750-890^{\circ} \mathrm{C}$ and pressures of $400-560 \mathrm{MPa}$, corresponding to $15-22 \mathrm{~km}$ depth. A hot crustal geotherm of $40^{\circ} \mathrm{C} \mathrm{km}^{-1}$ is required to explain the estimated deformation conditions. Infrared spectroscopy shows that plagioclase in the mafic granulites is relatively dry. Microstructures are interpreted to show that deformation in both the uppermost lower crust and upper mantle was accommodated by a combination of dislocation creep and grain-size-sensitive creep. Recrystallized grain size paleopiezometry yields low differential stresses of $12-33$ and $17 \mathrm{MPa}$ for plagioclase and olivine, respectively. The lower range of stresses (12$17 \mathrm{MPa}$ ) in the mafic granulite and lherzolite xenoliths is interpreted to be associated with transient deformation under decreasing stress conditions, following an event of stress in-
\end{abstract}

crease. Using flow laws for dry plagioclase, we estimated a low viscosity of $1.1-1.3 \times 10^{20} \mathrm{~Pa} \cdot \mathrm{s}$ for the high temperature conditions $\left(890^{\circ} \mathrm{C}\right)$ in the lower crust. Significantly lower viscosities in the range of $10^{16}-10^{19} \mathrm{~Pa} \cdot \mathrm{s}$, were estimated using flow laws for wet plagioclase. The shallow upper mantle has a low viscosity of $5.7 \times 10^{19} \mathrm{~Pa} \cdot \mathrm{s}$, which indicates the lack of an upper-mantle lid beneath northern Baja California. Our data show that during post-seismic transients, the upper mantle and the lower crust in the Pacific-Baja California plate boundary are characterized by similar and low differential stress. Transient viscosity of the lower crust is similar to the viscosity of the upper mantle.

\section{Introduction}

The rheology of lower crust in plate boundary zones is poorly constrained. Experimentally derived flow laws suggest relatively low long-term strength for the lower crust, particularly with respect to the middle crust and uppermost mantle, when the latter is dry (e.g., Brace and Kohlstedt, 1980; Kohlstedt et al., 1995). In contrast, a relatively strong lower crust is suggested by post-seismic relaxation studies (e.g., Pollitz et al., 2001; Freed and Bürgmann, 2004; Thatcher and Pollitz, 2008) and the presence of earthquakes in the lower crust (e.g., Jackson, 2002; Reyners et al., 2007). Generalization of lower-crustal rheology is difficult to assess because of its compositional heterogeneity. 
High-temperature deformation of plagioclase, the major rock-forming mineral in the lower crust, has been studied in the laboratory under the two end-member deformation mechanisms of grain-size-insensitive dislocation creep and grain-size-sensitive diffusion creep (Wilks and Carter, 1990; Rybacki and Dresen, 2000; Dimanov and Dresen, 2005). However, deformation of plagioclase by dislocationaccommodated grain boundary sliding, a mechanism transitional between grain-size-insensitive and grain-size-sensitive creep, is being recognized more commonly as a key process in naturally deformed plagioclase-bearing rocks (Kruse and Stünitz, 1999; Kenkmann and Dresen, 2002; Mehl and Hirth, 2008; Svahnberg and Piazolo, 2010; Hansen et al., 2013; Miranda et al., 2016). It is therefore important to understand how the activity of such a transitional deformation mechanism influences the rheological behavior of the lower crust in actively deforming regions.

In this study, we investigate the rheology of the continental lower crust and upper mantle by analyzing microstructures preserved in granulite and lherzolite xenoliths from northern Baja California, Mexico. The xenoliths were entrained in basalts erupted in the upper Pleistocene-Holocene San Quintín volcanic field located $\sim 20 \mathrm{~km}$ east of the Baja California shear zone (Fig. 1). The Baja California shear zone accommodates the relative movement between the Pacific plate and the Baja California microplate (e.g., Dixon et al., 2000; Plattner et al., 2009). Microstructures from the San Quintín lower-crustal and upper-mantle xenoliths allow us to investigate the active deformation mechanisms and viscosity structure of the lithosphere near an active strike-slip plate boundary. In this study, we mainly focus on the lower-crustal xenoliths.

\section{Geological setting}

\subsection{Geology of the Baja California microplate}

The Baja California microplate coincides broadly with the Baja California peninsula and comprises a lithospheric fragment within the Pacific-North America plate boundary (Fig. 1). The Baja California microplate formed by tectonic interaction of the Pacific, Farallon, and North American plates (e.g., Atwater and Stock, 1998). Transcurrent motion along the western margin of the North American plate started at $29 \mathrm{Ma}$, when the Pacific-Farallon spreading center arrived at the trench of the eastward subduction of the Farallon plate beneath North America (Atwater, 1989; Stock and Hodges, 1989). At ca. $12 \mathrm{Ma}$, deformation along the PacificNorth American plate margin was characterized by significant kinematic partitioning with a component of dextral strike-slip motion along the San Benito and Tosco-Abreojos fault zones, west of the Baja California peninsula, and extension in the future Gulf of California area (Stock and Hodges, 1989). Gradual plate boundary migration from west to east

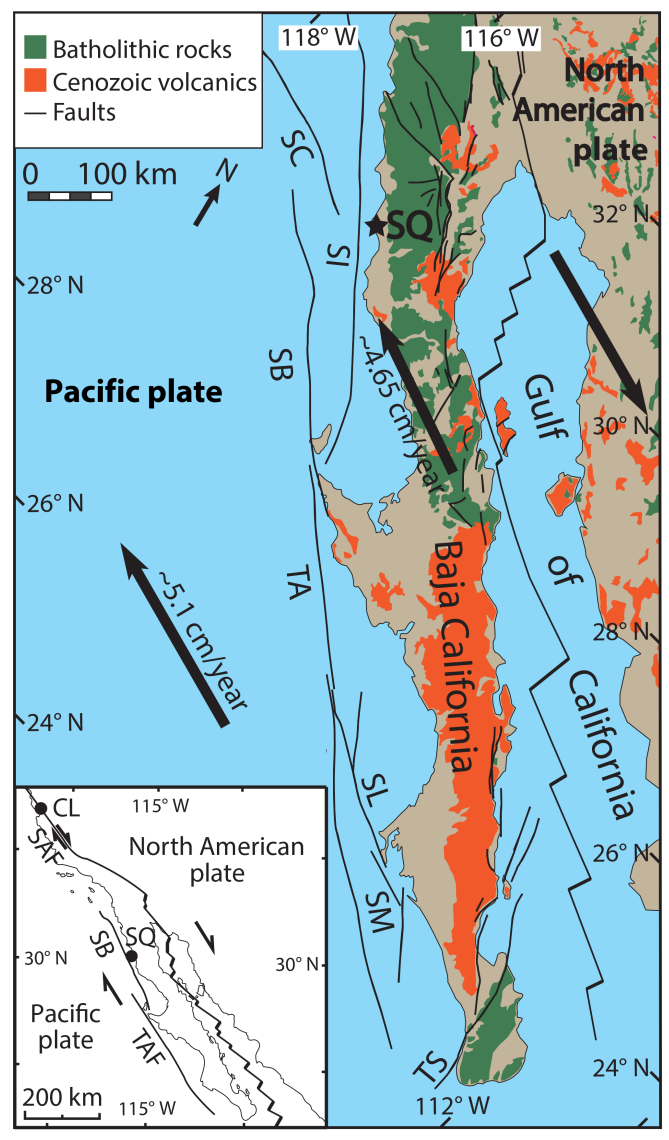

Figure 1. Geological map of Baja California, Mexico, showing the location of the San Quintín volcanic field (SQ) (modified after Langenheim and Jachens, 2003). The San Clemente (SC), San Isidro (SI), San Benito (SB), Tosco-Abreojos (TA), San Lazaro (SL), Santa Margarita (SM), and Todos Santos (TS) faults comprise parts of the Baja California shear zone. Arrows indicate the relative movement of the Pacific plate and the Baja California microplate with that of the North American plate (Plattner et al., 2007). Inset is a tectonic map of the Pacific-North American plate boundary, showing the location of the Baja California shear zone and the San Quintín volcanic field relative to the San Andreas fault (SAF) and the Coyote Lake volcanic field (CL).

of the Baja California peninsula, took place between 12 and 3.6 Ma and led to the transfer of Baja California from the North American plate to the Pacific plate (e.g., Stock and Hodges, 1989). Subsequent transfer of the strike-slip motion to the Gulf of California region led to continental separation of the Baja California peninsula from North America at ca. 3.6 Ma (DeMets, 1995).

Geological observations and GPS measurements show that Baja California behaves as a rigid block (Gastil et al., 1975; Umhoefer and Dorsey, 1997; Plattner et al., 2007). The direction of motion of the Pacific plate and Baja California relative to North America is similar, but Baja California moves at a rate that is $\sim 10 \%$ slower than the Pacific plate 
(Dixon et al., 2000; Plattner et al., 2007). Thus, Baja California behaves as a separate microplate, which is only partially coupled to the Pacific plate (Dixon et al., 2000; Plattner et al., 2007, 2009). Dixon et al. (2000) suggest that the relative movement between the Pacific plate and the Baja California microplate is accommodated by offshore slip along several active fault zones, collectively named the Baja California shear zone. The Baja California shear zone includes the San Clemente-San Isidro fault zone along northern Baja California (Legg et al., 1991) and may continue southward to the Tosco-Abreojos (Spencer and Normark, 1979), the Santa Margarita-San Lazaro (Fletcher et al., 2000), and/or the Todos Santos fault zones (Fletcher and Munguía, 2000) (Fig. 1).

The Baja California microplate consists primarily of the $\sim 800 \mathrm{~km}$ long Peninsular Ranges batholith (Fig. 1). The batholith is subdivided into a western and eastern plutonic zone, which reflect intrusions into the crust of oceanic and continental affinity, respectively (Gastil, 1975; Silver and Chappel, 1988). The western zone of the batholith consists of Middle Jurassic to middle Cretaceous plutons ranging in composition from gabbro to tonalite (Silver and Chappel, 1988; Tate and Johnson, 2000; Johnson et al., 1999). The plutonic bodies intrude lower greenschist grade metamorphic rocks of volcanic arc assemblage and are variably overprinted by subsolidus ductile deformation (Gastil, 1975; Todd et al., 1988). The eastern zone is dominated by early Mesozoic to Late Cretaceous plutons of tonalite, granodiorite, and granite composition (Gastil, 1975; Silver and Chappel, 1988; Johnson et al., 1999). These plutons intrude Paleozoic sedimentary rocks, which have been metamorphosed to upper greenschist and amphibolite facies conditions (Gastil and Miller, 1993). Regional metamorphism and deformation in the Baja California peninsula took place synchronously with the intrusion of the Peninsular Ranges batholith (Gastil, 1975; Todd et al., 1988). The mafic composition of the western Peninsular Ranges batholith produces magnetic anomalies and seismic velocity contrast, which can be traced down to at least $20 \mathrm{~km}$ depth (Langenheim and Jachens, 2003). The crustal thickness increases from 21 to $26 \mathrm{~km}$ along the eastern Baja California peninsula to 29-38 km below the western Peninsular Ranges batholith (Lewis et al., 2001; Paulssen and De Vos, 2017).

Geophysical studies reveal a complex, heterogeneous upper-mantle structure underneath the Baja California peninsula and the Gulf of California (Long et al., 2010; Zhang and Paulssen, 2012). The presence of a high shear-wave velocity anomaly beneath the central and southern Gulf of California has been interpreted as a slab fragment derived from the Farallon plate (Zhang and Paulssen, 2012). Low shearwave velocity beneath the northern Baja California peninsula has been attributed to asthenospheric upwelling within a slab window (Zhang et al., 2012; Paulssen and De Vos, 2017). The existence of a slab window beneath the northern part of the peninsula was also inferred from plate reconstructions and volcanism (Atwater, 1989; Dickinson, 1997). The fast propagation direction of surface waves in the crust and uppermost mantle beneath northern Baja California are plateboundary parallel, whereas at deeper levels $(50-150 \mathrm{~km})$ the fast anisotropic directions of the Rayleigh wave phase velocities are oriented $\mathrm{E}-\mathrm{W}$ - oblique to the plate boundary (Zhang et al., 2009).

\subsection{The San Quintín volcanic field}

Cessation of the subduction of Farallon-derived microplates at ca. $12 \mathrm{Ma}$ was followed by the eruption of several Miocene-Holocene volcanic fields of basaltic to rhyolitic composition along the Baja California peninsula. The northernmost volcanic field is the Upper Pleistocene-Holocene San Quintín volcanic field (Fig. 1), in which the eruptive activity continued until less than 5000-6000 years ago (Gastil, 1975; Rogers et al., 1985; Luhr et al., 1995). The San Quintín volcanic field is unique in Baja California because of the intraplate-type olivine alkali basalts, carrying upper-mantle peridotites and lower-crustal granulites (Basu, 1975; Rogers et al., 1985; Storey et al., 1989; Luhr et al., 1995). The geochemical signature of the San Quintín intraplate-type basalts points to an asthenospheric source, potentially related to the formation of a slab window beneath northern Baja California as a result of Pacific-Farallon ridge subduction (Storey et al., 1989).

The most important sources of xenoliths in the San Quintín volcanic field are the two northernmost volcanic complexes of Media Luna and Woodford, the volcanic rocks of which are the most differentiated in terms of composition (Basu, 1975; Luhr et al., 1995). The upper-mantle xenoliths are highly deformed (Basu, 1977; Cabanes and Mercier, 1988) and provide evidence for a low-viscosity upper mantle (Palasse et al., 2012). Two groups of strained peridotites have been recognized: (1) coarse-grained with equilibrium conditions of $T=1000-1050^{\circ} \mathrm{C}$ and $P<2000 \mathrm{MPa}$ and (2) porphyroclastic and mosaic with equilibrium conditions of $T=800-950{ }^{\circ} \mathrm{C}$ and $P \leq 1000 \mathrm{MPa}$ (Basu, 1977; Cabanes and Mercier, 1988). Deformation in the shallow upper mantle has been interpreted to be associated with active shear zones, which accommodate the relative motion between the Baja California microplate and the Pacific plate (Cabanes and Mercier, 1988; Palasse et al., 2012). In contrast to the upper-mantle xenoliths, deformation processes in the lower-crustal xenoliths and their extraction depths are poorly constrained.

\section{Methods}

\subsection{Sample collection and description}

We collected crustal and upper-mantle xenoliths from the Media Luna (samples starting with the code SQL) and Woodward (SQW) volcanic complexes, which are $3 \mathrm{~km}$ apart and comprise the two northern volcanic complexes of the San 
Quintín volcanic field (Fig. 1b; Luhr et al., 1995). The maximum length of the sampled xenoliths ranges between 5 and $25 \mathrm{~cm}$. One upper-mantle xenolith was analyzed for comparison. Crustal xenoliths are scarce compared to the uppermantle xenoliths in both volcanic complexes; a total of 22 crustal xenoliths were sampled ( 8 from Media Luna and 14 from Woodward). They are subdivided in gabbros (8 samples) and granulites (14 samples). Based on our small sample collection, gabbroic and granulite xenoliths are equally common in the Media Luna volcanic complex (3 out of 8 sampled crustal xenoliths are granulites), while granulite xenoliths are more common in the Woodward volcanic complex (11 out of 14 sampled crustal xenoliths). Where possible, we visually determined the foliation and lineation in each crustal xenolith using the alignment and elongation of pyroxene grains, in conjunction with the banding between plagioclase- and pyroxene-rich layers. Where a mineral shape fabric was identified, we constructed thin sections oriented parallel to the lineation and perpendicular to the foliation. We also investigated one lherzolite xenolith - whose microstructure, crystallographic texture, and seismic anisotropy were previously documented by Palasse et al. (2012) - in order to evaluate the mechanical properties of the upper mantle.

\subsection{Analysis of mineral chemistry, geothermometry, and phase equilibria}

Mineral major and minor element compositions were determined using wavelength-dispersion spectrometry (WDS) with a JEOL JXA-8530F HyperProbe field emission electron probe microanalyzer in the electron microscopy facility at Utrecht University and using energy-dispersive spectrometry (EDS) on the JEOL field emission gun scanning electron microscope at the Naturalis Biodiversity Center in Leiden. Operating conditions were $15 \mathrm{kV}$ accelerating voltage, $20 \mathrm{nA}$ beam current, and a beam diameter of $1 \mu \mathrm{m}$. Compositions were determined for cores and rims in each phase, and where possible, adjacent grains were analyzed. Equilibration temperatures were determined by application of two different calibrations of the two-pyroxene geothermometer, namely, those by Brey and Köhler (1990) (BK90) and Taylor (1998) (T98). Temperatures were calculated at an assumed pressure of $560 \mathrm{MPa}$, corresponding to the maximum pressure constrained by phase equilibria modeling. The effect of pressure on the estimated two-pyroxene temperatures is only $0.02^{\circ} \mathrm{C} \mathrm{MPa}^{-1}$. Phase equilibria for three crustal xenoliths were computed using Perple_X (Connolly and Petrini, 2002 , version 07 ). The updated internally consistent thermodynamic data set of Holland and Powell (1998; 2002 updated version) was used to construct the $P-T$ pseudosections, and the relevant solution models come from the Perple_X solution model files.

\subsection{Water content analysis}

To determine the $\mathrm{H}_{2} \mathrm{O}$ contents of plagioclase grains, we measured the infrared spectra of individual plagioclase grains using a JASCO IRT-30 infrared microscope that is attached to a JASCO FT/IR-470 plus Fourier transform infrared spectrometer housed at the Experimental rock deformation/HPT lab, in the Department of Earth Sciences, at Utrecht University. The microscope is equipped with a mercury cadmium tellurium (MCT) detector cooled by liquid nitrogen. The sample stage is built into a chamber that is constantly supplied by nitrogen gas during the measurements to reduce the influence of $\mathrm{CO}_{2}$ gas and $\mathrm{H}_{2} \mathrm{O}$ vapor. Grains of the samples were not oriented and the IR light was unpolarized. An aperture of $100 \times 100 \mu \mathrm{m}$ was used to select areas free of cracks, optical-scale inclusions, and boundaries under the microscope. Infrared spectra were first taken without the samples to remove the radiation background from sample measurements. The spectra were measured at room temperature, compiling 150 scans for each spectrum collected between wave numbers of 1 and $4000 \mathrm{~cm}^{-1}$ with a resolution of $4 \mathrm{~cm}^{-1}$ at room temperature. Spectra were collected from at least five grains in each sample. The thickness of the analyzed samples was $500 \mu \mathrm{m}$. Absorbances were determined quantitatively (recording peak height above background and integrated area below the peaks) using the JASCO software. Most spectra had sloping backgrounds due to scattering, which were adjusted using the JASCO software. The $\mathrm{H}_{2} \mathrm{O}$ content in plagioclase was determined using the BeerLambert law constrained by the calibration of Johnson and Rossman (2003). Because the orientation of the grains is unknown, we compared our measurements of integrated absorbances of $\mathrm{OH}$ bands in unpolarized IR spectra with the integrated absorbances in the three principal vibration directions of anorthite, digitizing polarized spectra of Johnson and Rossman (2003; their Fig. 1a). Using the ratios between these values and the total integrated absorbance, we determined the minimum and maximum values for the integrated absorbance for three principal vibrational directions to obtain upper and lower bounds for $\mathrm{H}_{2} \mathrm{O}$ content based on our unpolarized spectra, rather than reporting a single number (Table $\mathrm{S} 1$ in the Supplement). This approach gives a range of $\mathrm{OH}$ contents for unpolarized IR, within which the $\mathrm{OH}$ content is estimated conservatively, given that radiation with vibrational directions other than the principal maximum and minimum absorbances are also included in unpolarized IR measurements. Somewhat lower bounds for water content are given when we use the same procedure for the more recent calibration of Mosenfelder et al. (2015).

\subsection{Analysis of crystallographic preferred orientations}

Thin sections were mapped using scanning electron microscopy (SEM) in combination with electron backscatter diffraction (EBSD). Automated EBSD data acquisition was 
performed using a FEI XL30S field emission SEM instrument equipped with an Oxford Instruments NordlysNano EBSD detector at the EM square facility at Utrecht University. Large area $\left(\sim 200 \mathrm{~mm}^{2}\right)$ crystallographic orientation maps were acquired using the Oxford Instruments AZtecHKL acquisition and analysis software (version 3.0). A step size of $10 \mu \mathrm{m}$ was used. Post-acquisition data treatment involved processing of EBSD maps using the HKL Channel5 software package. Processing included (1) removal of isolated single pixels differing by more than $10^{\circ}$ from their neighbors and (2) assignment of the average orientation of neighboring pixels to non-indexed pixels with the eight nearest neighbors. This operation was iterated until no new pixels were filled and was repeated for non-indexed pixels with a decreasing number of nearest neighbors as low as five. To quantify the strength of olivine crystallographic preferred orientation (CPO) we used the $J$ index (Bunge, 1982) and $M$ index (Skemer et al., 2005).

\subsection{Grain size analysis and paleopiezometry}

To determine the mean recrystallized grain size of plagioclase, clinopyroxene, and olivine, we used the equivalent circular diameter method on grains defined by a grain boundary misorientation angle of $10^{\circ}$, constructed from the EBSD data in the HKL Channel5 software. We used the opensource GrainSizeTools script (Lopez-Sanchez and LlanaFúnez, 2015) to construct grain size distributions of the number-weighted equivalent circular diameters. We determined the arithmetic mean from the grain size distributions. To convert between the mean equivalent circular diameter on a two-dimensional section and the mean grain size in three dimensions, a scaling factor of 1.2 was used (Underwood, 1970).

For viscously deforming rocks, the paleopiezometric relationship that relates the recrystallized grain size to the differential stress has the form

$\sigma=B d^{-n}$,

where $\sigma$ is the differential stress, $d$ is the recrystallized grain size, and $B$ and $n$ are empirically derived constants. To estimate differential stress for plagioclase, we used the theoretical paleopiezometer of Twiss (1977), for clinopyroxene the calibration of Avé Lallement (1978), and for olivine the calibration of Van der Wal et al. (1993). In one olivine-bearing granulite, we estimated the mean olivine subgrain size using the linear intercept method on an EBSD map (Valcke et al., 2006). To define the lower limit of subgrain and grain boundaries we used a misorientation angle of 1 and $10^{\circ}$, respectively. To convert between mean intercept length on a two-dimensional section and the mean grain diameter in three dimensions, a scaling factor of 1.5 was used (Underwood, 1970). We used the subgrain-size paleopiezometer of Toriumi (1979) to estimate the range of differential stresses for olivine.

\section{Results}

\subsection{Microstructures}

Microstructures in the San Quintín xenoliths were studied using combined light (Fig. 2) and electron microscopy (e.g., SEM-BSE and EBSD maps; Fig. 3) techniques. The gabbroic xenoliths have a cumulate microstructure, characterized by the crystallization of earlier pyroxenes and interstitial growth of optically continuous pools of plagioclase (Fig. 2a). Plagioclase grains in gabbros are centimeter sized and contain growth twins. The rare presence of tapered deformation twins and the lack of undulatory extinction indicate that plagioclase in the gabbroic xenoliths is only weakly deformed by plastic mechanisms.

Granulites have a compositional foliation defined by alternating plagioclase- and pyroxene-rich domains (Fig. 3a). The pyroxene-rich domains form elongated lenses, aligned parallel to the foliation (Figs. 2b and 3a). The granulite xenoliths have a granoblastic microstructure; plagioclase and pyroxenes are characterized by gently curved to straight grain and/or phase boundaries, which lead to polygonal grain shapes with approximately $120^{\circ}$ triple junctions (Fig. 3c). Grain and phase boundaries of plagioclase and pyroxene may also be either concave or straight and aligned (Figs. 2c and $3 \mathrm{c}, \mathrm{d})$. Straight and aligned grain boundaries are associated with the formation of quadruple junctions (Figs. 2e and $3 \mathrm{c}, \mathrm{d})$. Large plagioclase grains (porphyroclasts) contain deformation twins, and show undulose extinction, and the formation of subgrain boundaries concentrated along grain boundaries (Fig. 3b). Smaller, recrystallized plagioclase grains are usually devoid of mechanical twins; where present, the twins trend parallel to the mechanical twins of neighboring plagioclase porphyroclasts. In an attempt to quantify our microstructural observations, we visually inspected the type of triple junctions in three granulite xenoliths. In each xenolith we inspected a large number of grain triple junctions (314-834). We discriminated between stable, $\sim 120^{\circ}$ triple junctions and unstable $\left(\neq 120^{\circ}\right)$ triple junctions. In all three xenoliths, the majority of triple junctions (78-92\%) show an unstable configuration. In xenoliths SQ16, SQW-110, and SQW-75, 6, 15, and $21 \%$ of the triple junctions, respectively, are stable. This result suggests that there is a difference in the microstructure between the xenoliths, with samples SQW-110 and SQW-75 being partly affected by static recrystallization and characterized by a partial foam microstructure (see Kidder et al., 2016). A highly equilibrated microstructure due to extensive static recrystallization is not observed in the analyzed xenoliths.

Clinopyroxene grains exhibit core-and-mantle structures (Fig. 2b); the clinopyroxene porphyroclasts show undulose extinction and are surrounded by smaller recrystallized clinopyroxene and orthopyroxene grains. Formation of subgrain boundaries in the clinopyroxene porphyroclasts is concentrated along grain boundaries. Clinopyroxene porphyro- 

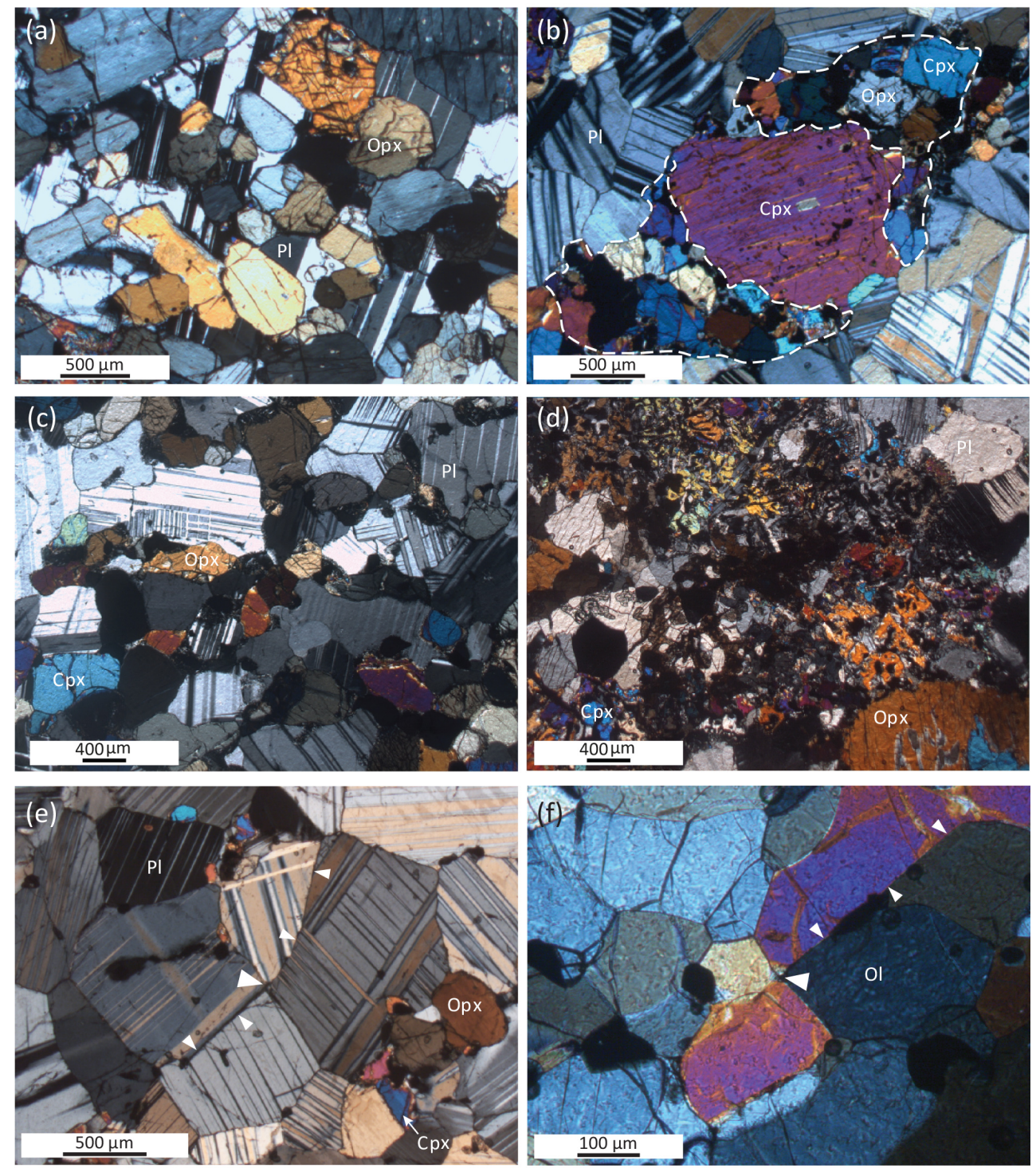

Figure 2. Typical microstructures in the San Quintín gabbroic and mafic granulite xenoliths. All photomicrographs are taken under crossedpolarized light. (a) Cumulate microstructure of the gabbroic xenolith SQL-13A characterized by crystallized pyroxenes and interstitial plagioclase. (b) Core-and-mantle microstructure of clinopyroxene in granulite xenolith SQW-75. The elongated cluster of clinopyroxene and orthopyroxene defines the foliation (upper right to lower left) in the granulite. White dashed lines describe the mantle of clinopyroxene and orthopyroxene recrystallized grains surrounding the clinopyroxene core. (c) Granoblastic microstructure with interlobate boundaries between plagioclase grains in xenolith SQW-110. (d) Melt patch between pyroxene and plagioclase aggregates in SQ-16. (e) Granoblastic microstructure in granulite SQW-75. Large plagioclase grains with straight grain boundaries (small white triangles) meeting at $120^{\circ}$ triple junctions and at quadruple junctions (larger white triangle in the center). (f) Equigranular mosaic microstructure in lherzolite xenolith SQ-68. Quadruple junction (large white triangle in the center) associated with straight and aligned grain boundaries (described by the small white triangles) of olivine grains.

clasts show thin orthopyroxene exsolution lamellae (e.g., SQW-75; Fig. 2b), which are attributed to cooling.

Olivine in the crustal xenoliths is either present in symplectites with intergrown pyroxenes, plagioclase, and spinel (Fig. $4 \mathrm{a}, \mathrm{b}$ ), or forms rims around pyroxene grains. In both types of microstructure, olivine is fine grained and shows no evidence of intracrystalline deformation. The two- pyroxene granulite SQ-16 is the only xenolith containing lenses of cumulate olivine (Fig. 3a). This type of olivine is coarse grained, shows undulose extinction, and exhibits development of subgrain boundaries oriented perpendicular or oblique (at high angle) to the foliation. Straight to concave olivine-olivine grain boundaries, leading to polygonal crystal shapes with $120^{\circ}$ triple junctions, are indicative of an 

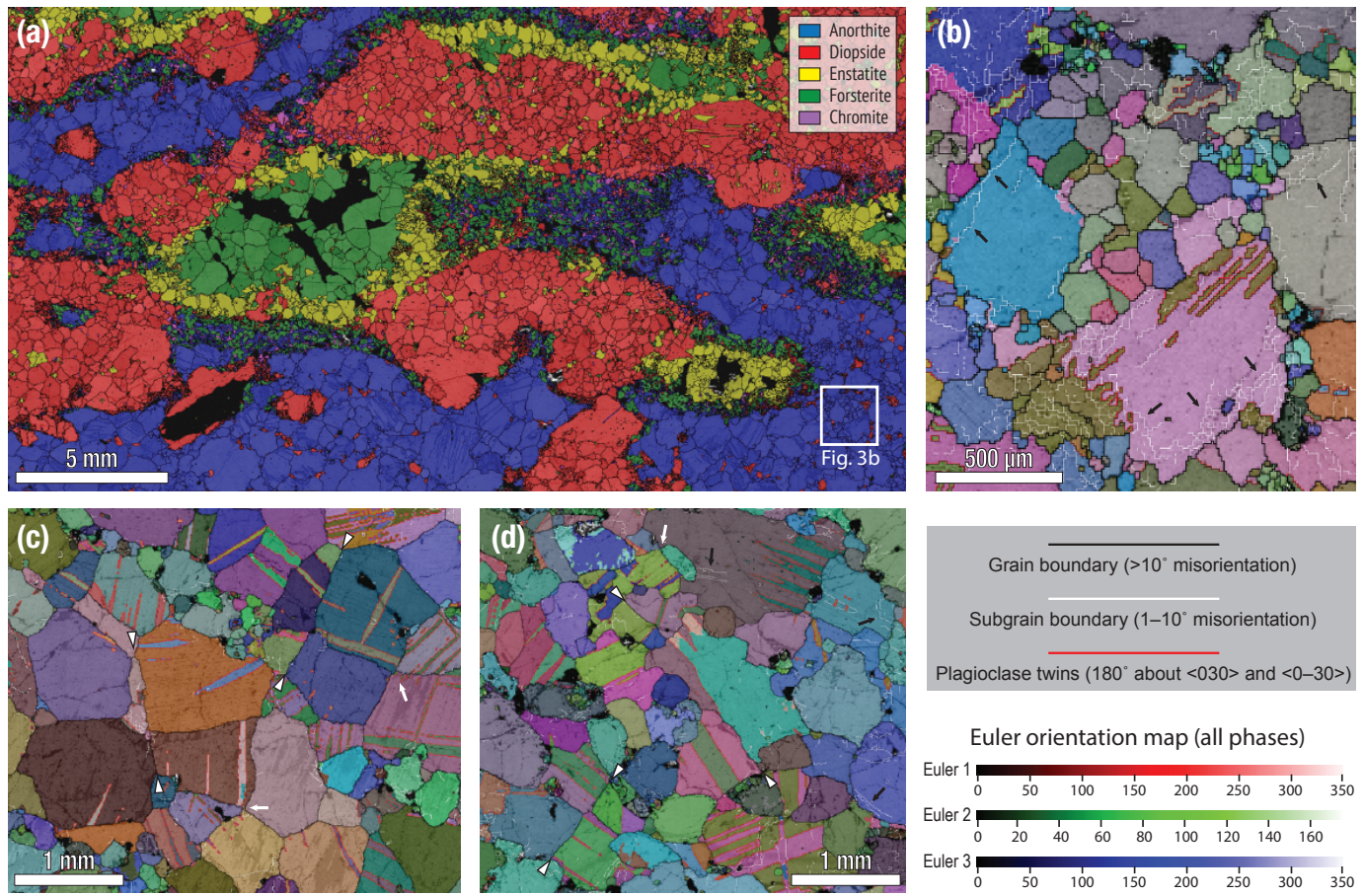

Figure 3. Examples of EBSD maps. All maps have an upper edge parallel to the observed lineation, with the foliation being normal to the map. (a) EBSD phase map layered on a band contrast map in granulite SQ-16. Please note the enstatite rims on olivine. (b-d) EBSD maps of Euler orientation layered on band contrast maps. The white box in (a) shows the location of (b). Panel (c) shows xenolith SQW-75 and panel (d) shows SQW-115. Black arrows show subgrain boundaries in plagioclase. White arrows point to quadruple junctions. White triangles delineate aligned grain boundaries.

equilibrium microstructure. This olivine type is rimmed by a thick orthopyroxene corona, which may result from the reaction between olivine and basaltic melt. Importantly, olivine in the lens is Mg-rich and the only among the xenoliths lacking $\mathrm{Fe}^{3+}$ and Mn (Table S2). In some xenoliths (e.g., SQW-115; Fig. 4c), orthopyroxene grains have large olivine rims, which is opposite from the orthopyroxene coronas on xenocrystic olivine in SQ-16. In SQW-115, EDS and WDS analyses revealed the presence of clinopyroxene and plagioclase in the coronas, in addition to olivine.

Further information about late processes that involve melt-rock interaction and late oxidation is provided by the following microstructural observations: (1) symplectites in SQW-75 (Fig. 4a) show intergrowths of spinel, orthopyroxene, plagioclase, and olivine that appear to be derived from the breakdown of an earlier generation of clinopyroxene; some involvement of a high- $T$ anhydrous basaltic melt is likely, as it facilitates the reaction balance; (2) crystallized melt patches in some xenoliths (e.g., SQ-16) are unaffected by deformation (Fig. 2d and 3) and magnetite coronas resulting from late oxidation are present around spinel grains (Fig. 4d).

The lherzolite xenolith examined in this study (SQ-68) has an equigranular mosaic microstructure; it contains elongated (aspect ratio of $11: 1$ ) pyroxene porphyroclasts within a fine-grained matrix of equant olivine and pyroxene grains (Palasse et al., 2012). Complementing the microstructural observations of Palasse et al. (2012), we report the presence of straight and aligned grain boundaries, as well as quadruple junctions (Fig. 2f).

\subsection{Mineral content and chemistry}

The lower-crustal xenoliths have a mafic composition; they dominantly consist of plagioclase and clinopyroxene, with lesser amounts of orthopyroxene, olivine, and spinel. A few samples contain subordinate magnetite and ulvöspinel. A felsic granulite (SQW-76) sampled from the Woodward volcanic complex consists of plagioclase + quartz + orthopyroxene + magnetite + titanite. Table $\mathrm{S} 3$ shows the mineral content of each xenolith used for phase equilibria modeling (see Sect. 4.3). All mineral phases show multiple generations, with compositions commonly dependent on the microstructure. Most phases are chemically unzoned, except plagioclase. Table S2 shows representative mineral compositions determined with electron probe microanalysis.

Plagioclase is present in two general variations in all examined samples: (1) as relatively coarse porphyroclasts and recrystallized grains and (2) as small grains in the symplectite and exsolution structures. We focused our analyses on the recrystallized grains, which are unzoned and generally 

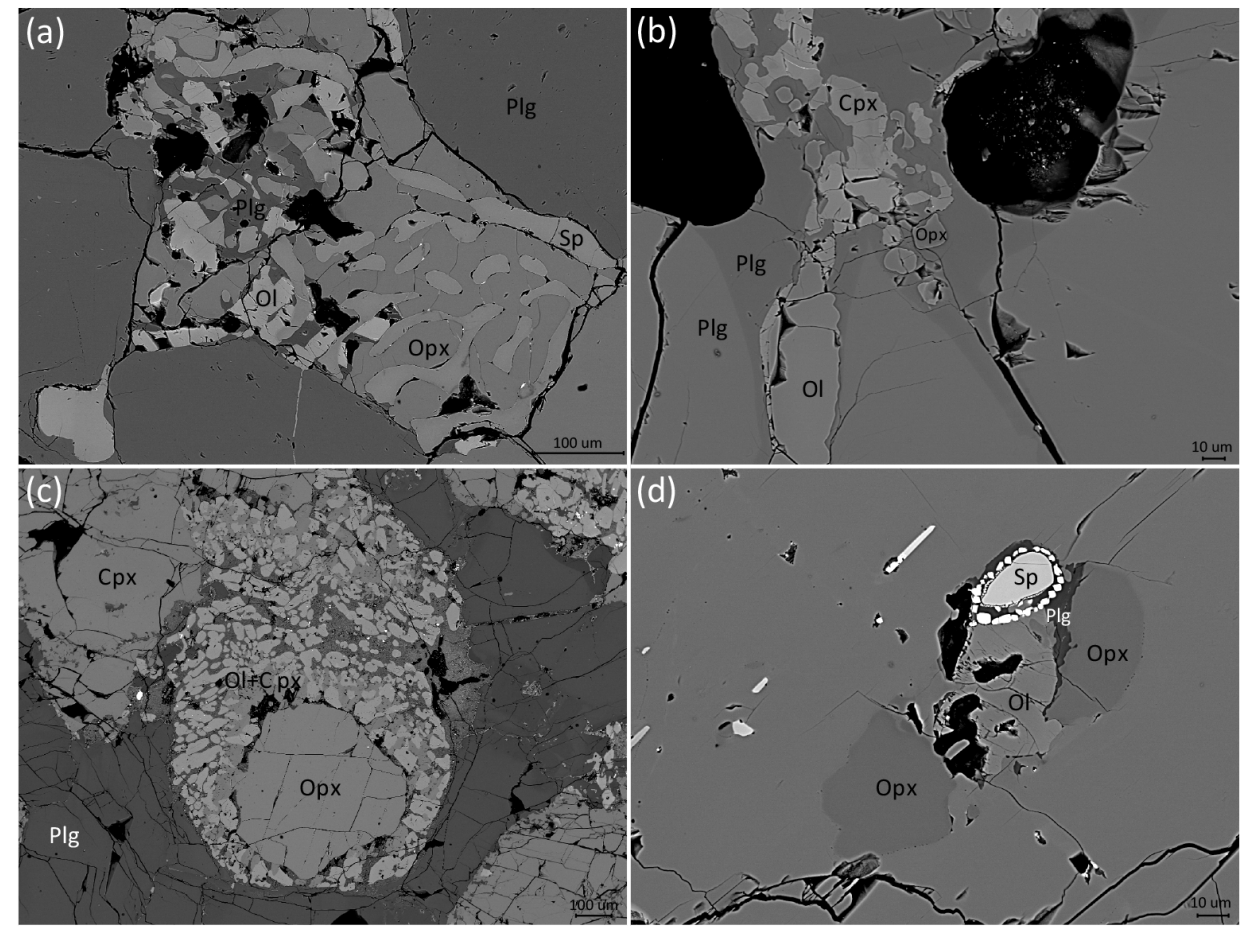

Figure 4. SEM-BSE images showing typical microstructures in the San Quintín xenoliths. (a) Symplectite with intergrown orthopyroxene, spinel, plagioclase, and olivine in SQW-75. (b) Melt patch containing plagioclase, olivine, clinopyroxene, and orthopyroxene. Compositional variation between two types of plagioclase can be seen in the lower left part of the image (SQW-114). (c) Orthopyroxene with a rim containing olivine, plagioclase, and clinopyroxene (SQW-115). (d) Inclusion in a clinopyroxene porphyroclast. The inclusion contains spinel with a magnetite rim, orthopyroxene, plagioclase, and olivine (SQW-75).

An-rich (> An80) (Fig. 5). The enderbitic sample SQW-76 has recrystallized grains with the lowest measured An content of An36. The plagioclase grains in symplectites locally show compositional zoning and have an anorthite content of An60-85. The orthoclase component is negligible in all samples.

Clinopyroxene shows no evidence for compositional zoning, except in sample SQW-115. Clinopyroxene composition does, however, vary somewhat between samples. In the symplectites of xenolith SQW-114 and rims of grains in SQW115 , clinopyroxene has a lower $\mathrm{CaO}$ and a higher $\mathrm{MgO}$ content compared to the cores of larger grains in these samples.

Orthopyroxene also lacks chemical zoning. Its composition depends on the microstructure and assemblage. In symplectites and exsolution structures, the $\mathrm{FeO}$ content is lower and $\mathrm{MgO}$ content higher than in primary grains. In addition, orthopyroxene has a higher $\mathrm{CaO}$ content in symplectites. The $\mathrm{Al}$ content is quite low.

Spinel forms part of a secondary microstructural configuration (symplectite, exsolutions, or altered rims). Spinel grains are Al-rich and have a large amount of ferric iron. The only exceptions are some Cr-rich spinel grains found in the clinopyroxene exsolution in sample SQW-75.

Olivine also generally forms part of a secondary microstructural configuration and has $\mathrm{X}_{\mathrm{Mg}}$ values ranging from

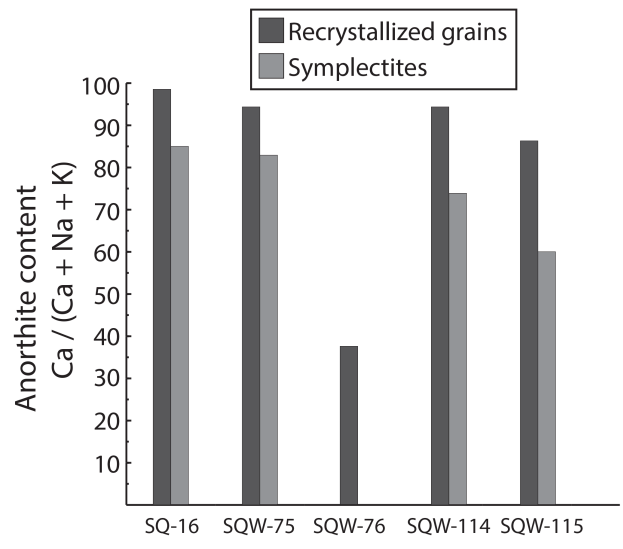

Figure 5. Histogram showing the anorthite content of recrystallized plagioclase grains and plagioclase grains in symplectites.

0.65 to 0.80 . The iron content is higher in the olivine of sample SQW-110 $\left(\mathrm{X}_{\mathrm{Mg}}=0.39\right)$. Large olivine crystals in SQ-16 comprise a primary structure (Fig. 3a); these olivine xenocrysts are rimmed by orthopyroxene and have the highest $\mathrm{X}_{\mathrm{Mg}}$ value (0.84). 

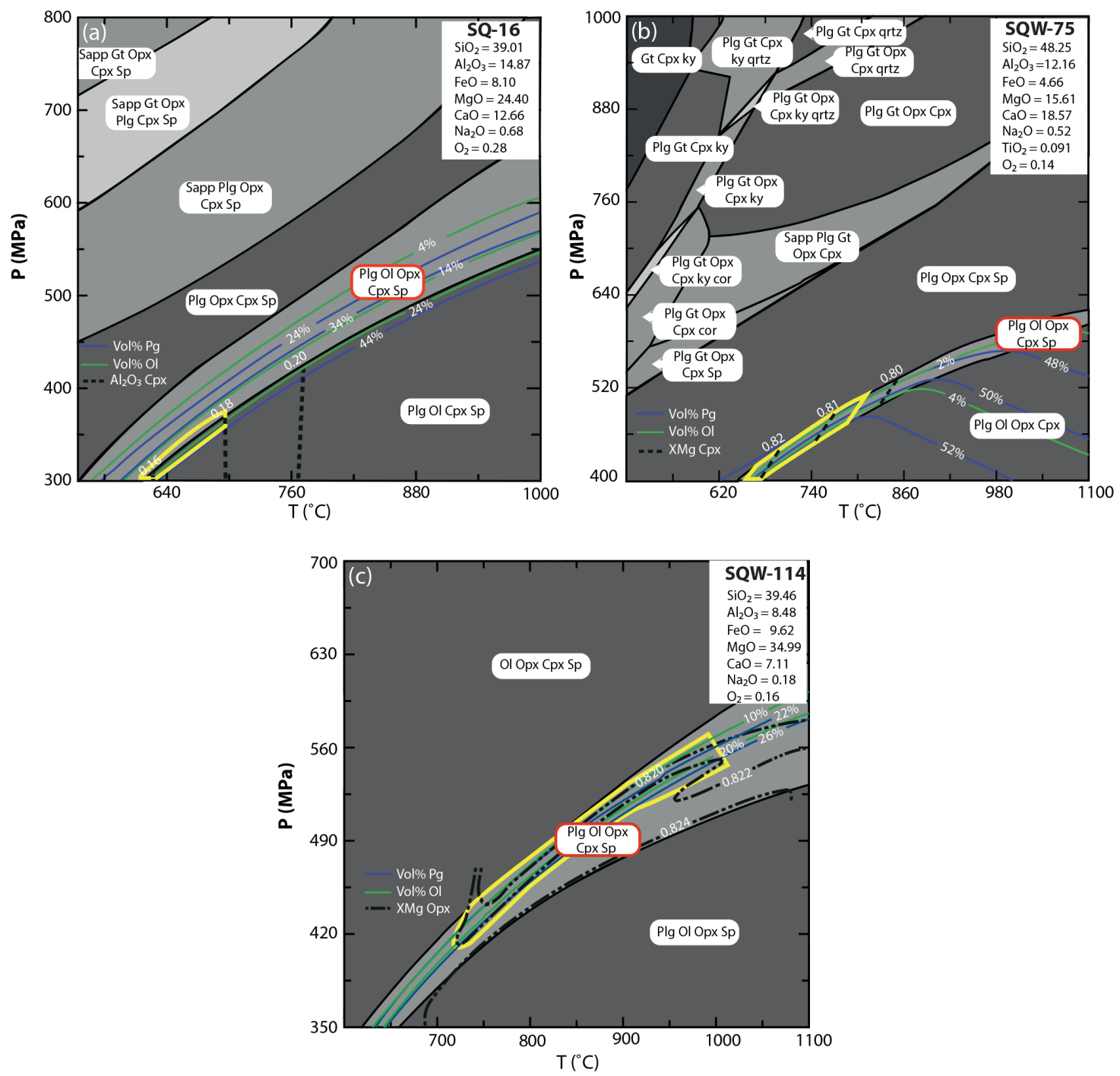

Figure 6. Constructed $P-T$ pseudosections for samples SQ-16, SQW 75, and SQW-114. Molar compositions are indicated in the text boxes. The observed mineral assemblage is indicated by a red outline and the stability field is indicated with a yellow outline. (a) SQ-16 pseudosection, with the dashed lines illustrating the range of $\mathrm{Al}_{2} \mathrm{O}_{3}$ in clinopyroxene. (b) SQW-75 pseudosection, with the dashed lines illustrating the range of the magnesium number in clinopyroxene. (c) SQW-114 pseudosection, with the dashed lines with dots describing the range of the magnesium number in orthopyroxene. The blue and green lines show the volume percentages of the xenoliths in plagioclase and olivine, respectively.

\section{3 $\quad P-T$ conditions}

$P-T$ pseudosections were reconstructed for three xenoliths, SQ-16, SQW-75, and SQW-114, using the Perple_X software, version 7.0. The pseudosections are based on microprobe data and estimates of volume percentages for specific microdomains. The determined volume percentages and magnesium numbers for each phase in a domain are shown in Table S3.

Figure 6 shows the constructed $P-T$ pseudosections. The stable mineral assemblages used for constructing the pseudosections are indicated with a red outline. The composition used for SQ-16 is stable between 615 and $700{ }^{\circ} \mathrm{C}$ (Fig. 6a). The volume percentages of the phases generally overlap on the boundary between the $\mathrm{Plg}+\mathrm{Ol}+\mathrm{Cpx}+\mathrm{Opx}+\mathrm{Sp}$ and $\mathrm{Plg}+\mathrm{Ol}+\mathrm{Cpx}+\mathrm{Sp}$ stability fields. This indicates that the pressure at that stage is between 300 and $370 \mathrm{MPa}$. The composition for SQ-16 was based on a symplectite microdomain and thus gives an indication of $P-T$ conditions postdating the peak. It lacks orthopyroxene, which is present in the general mineral assemblage of the sample. Hence, the peak pressure was probably higher for this sample. In addition, the sample shows evidence for cooling from higher $T$, resulting in thick coronas of orthopyroxene on xenocrys- 
Table 1. Equilibration temperature and pressure, grain size, and differential stress.

\begin{tabular}{|c|c|c|c|c|c|c|c|}
\hline \multirow[b]{2}{*}{ Xenolith } & \multirow[b]{2}{*}{$\begin{array}{r}\text { Mean 2-Px } T \\
\left({ }^{\circ} \mathrm{C}\right)\end{array}$} & \multicolumn{2}{|c|}{ Phase equilibria } & \multirow[b]{2}{*}{$\begin{array}{l}D_{\mathrm{plg}} \\
(\mu \mathrm{m})\end{array}$} & \multirow[b]{2}{*}{$\begin{array}{r}\sigma_{\mathrm{plg}} \\
(\mathrm{MPa})\end{array}$} & \multirow[b]{2}{*}{$\begin{array}{r}D_{\mathrm{ol}} \\
(\mu \mathrm{m})\end{array}$} & \multirow[b]{2}{*}{$\begin{array}{r}\sigma_{\mathrm{ol}} \\
(\mathrm{MPa})\end{array}$} \\
\hline & & $\begin{array}{r}T \\
\left({ }^{\circ} \mathrm{C}\right)\end{array}$ & $\begin{array}{r}P \\
(\mathrm{MPa})\end{array}$ & & & & \\
\hline SQ-16 & $751 \pm 27$ & $615-700$ & $300-370$ & 122 & 33 & 340 & 17 \\
\hline SQL-48 & $765 \pm 36$ & - & - & 346 & - & - & - \\
\hline SQW-75 & $759 \pm 25$ & $650-815$ & $400-520$ & 454 & 13 & - & - \\
\hline SQW-76 & - & - & - & 482 & - & - & - \\
\hline SQW-110 & $886 \pm 87$ & - & - & 528 & 12 & - & - \\
\hline SQW-114 & $886 \pm 32$ & $710-1015$ & $410-560$ & - & - & - & - \\
\hline SQW-115 & $854 \pm 28$ & - & - & 413 & - & - & - \\
\hline SQ-68 & - & - & - & - & - & 361 & 17 \\
\hline
\end{tabular}

tic olivine. In support of this interpretation are the higher equilibrium temperatures $\left(751 \pm 27^{\circ} \mathrm{C}\right)$ estimated from twopyroxene geothermometry (Table 1 ).

For SQW-75 the pseudosection was based on the whole rock mineral assemblage (Fig. 6b). This assemblage is stable between 650 and $815^{\circ} \mathrm{C}$ at $400-520 \mathrm{MPa}$. Olivine is a secondary phase in this sample and is only present in symplectites and exsolutions. Hence, similar to SQ-16, a stage of decompression has affected the sample.

The pseudosection for SQW-114 was constructed using volume estimates of a melt pocket. Isopleths for $\mathrm{X}_{\mathrm{Mg}}$ of orthopyroxene give a wide $P-T$ range of $710-1015^{\circ} \mathrm{C}$ and 410-560 MPa (Fig. 6c).

Equilibration temperatures in six xenoliths were estimated using two-pyroxene geothermometry (Table S4). The average temperature estimates range from $751 \pm 27$ to $886 \pm 87^{\circ} \mathrm{C}$ (Table 1) and fall in two groups: $751 \pm 27-765 \pm 36$ and $854 \pm 2-886 \pm 87^{\circ} \mathrm{C}$. The temperatures estimated from twopyroxene geothermometry for SQW-75 and SQW-114 overlap with the range of temperatures constrained from the $P-T$ pseudosections. In SQ-16, the symplectite microdomain that was used for $P-T$ pseudosection reconstruction yields lower temperatures compared to two-pyroxene geothermometry.

\subsection{Water content}

Water contents of plagioclase grains were measured in three xenoliths: two mafic granulites (SQW-78 and SQW-115) and one felsic granulite (SQW-76). Figure 7 shows representative spectra for three different grains of each sample in the 2800$4000 \mathrm{~cm}^{-1}$ range. This region includes the stretching vibration wave numbers of structural $\mathrm{OH}$ and the symmetrical and asymmetrical stretching vibrations of $\mathrm{H}_{2} \mathrm{O}$ molecules. There is a clear difference in the spectra of sample SQW-76 with broad $\mathrm{OH}$ absorption bands at 3250,3400 , and $3600 \mathrm{~cm}^{-1}$ (Fig. 7c) and the samples SQW-78 and SQW-115 with little or no evidence of large $\mathrm{OH}$ bands above background
(Fig. 7a, b). The $3250 \mathrm{~cm}^{-1}$ absorption band of SQW-76 corresponds well with $\mathrm{OH}$ bands of a number of plagioclases reported by Johnson and Rossman (2003), while the large $\mathrm{OH}$ bands at 3400 and $3600 \mathrm{~cm}^{-1}$ were absent from spectra of their plagioclase specimens. These bands resemble $\mathrm{OH}$ bands in other feldspars, and they may even reflect spectroscopic contributions of fluid inclusions (band at $3400 \mathrm{~cm}^{-1}$ ) and layer silicate inclusions (band at $3600 \mathrm{~cm}^{-1}$ ). SQW78 (Fig. 7a) shows bands at 2850 and $2950 \mathrm{~cm}^{-1}$ and at 3600 and $3700 \mathrm{~cm}^{-1}$. The bands at 2850 and $2950 \mathrm{~cm}^{-1}$ are due to $\mathrm{C}-\mathrm{H}$ bond stretching and are due to residual epoxy that was used in preparation of sample chips. SQW115 (Fig. 7b) shows small, sharp $\mathrm{OH}$ bands at 3600 and $3700 \mathrm{~cm}^{-1}$. Bands at $\sim 3700 \mathrm{~cm}^{-1}$ are commonly associated with alteration products such as layer silicates (Johnson and Rossman, 2003); thus, the actual water content may be lower. In addition, the traces of epoxy also contain $\mathrm{OH}$ and may contribute to estimates of water content. However, we have selected spectra for analysis with little or no epoxy, as judged by their small $\mathrm{C}-\mathrm{H}$ absorption bands. Plagioclase water contents of the mafic granulites vary from 7 to $317 \mathrm{ppm} \mathrm{H}_{2} \mathrm{O}$ $\left(7 \times 10^{-4}-3.2 \times 10^{-2} \mathrm{wt} \%\right)$, and they are much larger in the felsic granulite, from 151 to $4178 \mathrm{ppm}_{2} \mathrm{O}\left(1.5 \times 10^{-2}-\right.$ $4.2 \times 10^{-1} \mathrm{wt} \%$ ) (Table 2). Thus, our results indicate that plagioclase is relatively dry in the mafic granulites while wet in the felsic granulite, with variable local amounts of water from low to high values.

\subsection{Grain size and differential stress}

Grain size was analyzed in six granulite xenoliths and one lherzolite xenolith. Grain size distribution plots are shown in Fig. 8. In the following, mean grain size refers to the arithmetic mean of the grain size distribution, corrected for the two-dimensional sectioning of the grains. Because of the lack of monophase domains of plagioclase and clinopyroxene in granulites SQL-48, SQW-76, and SQW-115, grain sizes in 


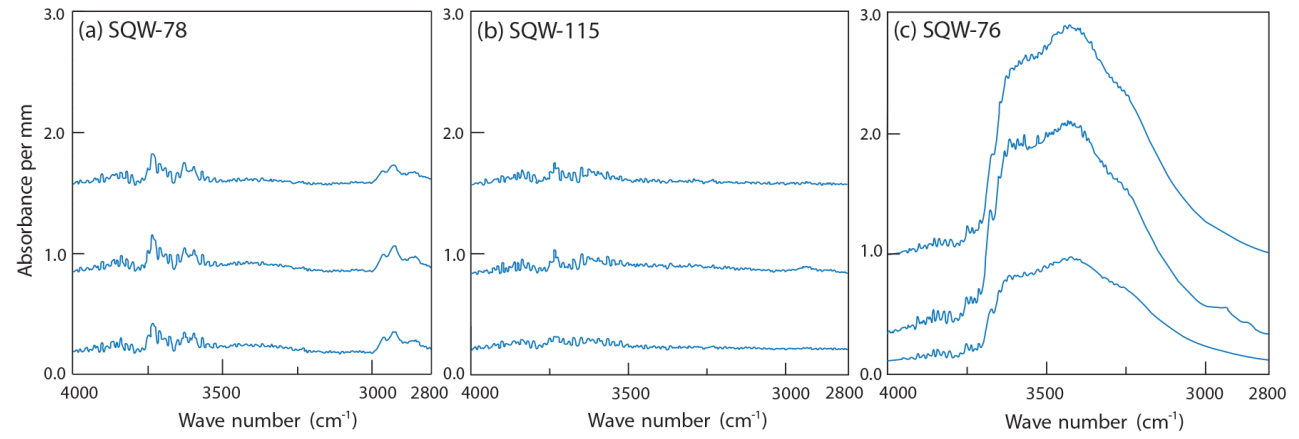

Figure 7. Representative IR spectra for plagioclase in the xenolith samples, with measured absorbances normalized to $1 \mathrm{~mm}$ sample thickness. (a) SQW-78, mafic granulite; (b) SQW-115, mafic granulite; and (c) SQW-76, felsic granulite.

Table 2. $\mathrm{H}_{2} \mathrm{O}$ concentrations in plagioclase.

\begin{tabular}{llrrrr}
\hline Xenolith & Rock type & $\begin{array}{r}\text { IR band area } \\
\left(\mathrm{cm}^{-2}\right)\end{array}$ & $\begin{array}{r}\text { Total band area } \\
\left(\mathrm{cm}^{-2}\right)\end{array}$ & ppm $\mathrm{H}_{2} \mathrm{O}$ wt \% & wt \% \\
\hline SQW-78 & Mafic granulite & $180-480$ & $237-4974$ & $15-317$ & $0.0015-0.032$ \\
SQW-115 & Mafic granulite & $80-420$ & $105-352$ & $7-278$ & $0.0007-0.029$ \\
SQW-76 & Felsic granulite & $1810-6320$ & $2382-65492$ & $151-4178$ & $0.015-0.42$ \\
\hline
\end{tabular}

these xenoliths were determined from polyphase domains and were not used for estimating the differential stress. In these three xenoliths, the grain size distributions of plagioclase and clinopyroxene are unimodal, with means of the distributions ranging from 346 to $482 \mu \mathrm{m}$ for plagioclase and from 354 to $500 \mu \mathrm{m}$ for clinopyroxene (Fig. 8). Thus, the mean grain size of plagioclase and clinopyroxene is similar in the polyphase domains.

In three mafic granulite xenoliths (SQ-16, SQW-75, and SQW-110), differential stress was estimated based on the grain size in monophase plagioclase and clinopyroxene domains. The monophase domains in two xenoliths (SQW75 and SQW-110) show unimodal grain size distributions (Fig. 8); the mean grain size of the unimodal distributions is 454 and $528 \mu \mathrm{m}$ for plagioclase and $256 \mu \mathrm{m}$ for clinopyroxene. These mean grain sizes correspond to a differential stress of $12-13 \mathrm{MPa}$ for plagioclase and $20 \mathrm{MPa}$ for clinopyroxene (Table 1). Plagioclase in xenoliths SQW-75 and SQW-110 exhibits a partial foam microstructure, which suggests that grain shape has been affected to some extent by grain-boundary energy-driven grain growth. Thus, the estimated differential stress for plagioclase does not record the highest stress levels in these two xenoliths. Xenolith SQ16 exhibits bimodal distributions of both plagioclase and clinopyroxene grain sizes (Fig. 8a, b). To estimate differential stress we used the recrystallized grains belonging to the group of finer plagioclase $(d<330 \mu \mathrm{m})$ and clinopyroxene $(d<148 \mu \mathrm{m})$ grains. The small plagioclase and clinopyroxene recrystallized grains usually occur as clusters either along the boundaries or within the areas of triple and quadruple junctions between porphyroclasts. The differen- tial stress estimated based on the mean grain size of the small recrystallized plagioclase $(d=122 \mu \mathrm{m})$ and clinopyroxene $(d=83 \mu \mathrm{m})$ grains is 33 and $70 \mathrm{MPa}$, respectively. We note that the solid pressure medium apparatus with a talc assembly used in the deformation experiments of Avé Lallement (1978) for the clinopyroxene paleopiezometer calibration may overestimate flow stress from $130 \%$ to more than $150 \%$ (Green and Borch, 1989; Stewart et al., 2013). Thus, the reported differential stresses for clinopyroxene may significantly overestimate the true flow stress.

To further constrain differential stress, we analyzed the grain size and subgrain size of olivine composing a monomineralic lens in xenolith SQ-16 (Fig. 8c). The mean olivine grain size is $340 \mu \mathrm{m}$, which corresponds to a differential stress of $17 \mathrm{MPa}$ (Table 1). The differential stress calculated from the mean olivine subgrain size $(217 \mu \mathrm{m})$ is $7 \mathrm{MPa}$ using the subgrain size paleopiezometer of Toriumi (1979). The subgrain size of olivine is similar to that of plagioclase $(228 \mu \mathrm{m})$ and clinopyroxene $(215 \mu \mathrm{m})$ in the same xenolith (SQ-16).

The lherzolite xenolith SQ-68 is characterized by alternation of monophase olivine layers and polyphase olivine + orthopyroxene + clinopyroxene layers. Both types of layers have unimodal olivine grain size distributions, such as the one shown in Fig. 8c for the monophase domains. Based on the mean olivine recrystallized grain size $(361 \mu \mathrm{m})$ in monophase olivine domains, we estimated a differential stress of $17 \mathrm{MPa}$ using the paleopiezometric calibration of Van der Wal et al. (1993) (Table 1). Olivine has a subgrain size of $236 \mu \mathrm{m}$, which corresponds to a differential stress of $6 \mathrm{MPa}$. The mean olivine grain size for the polyphase do- 
(a) Plagioclase
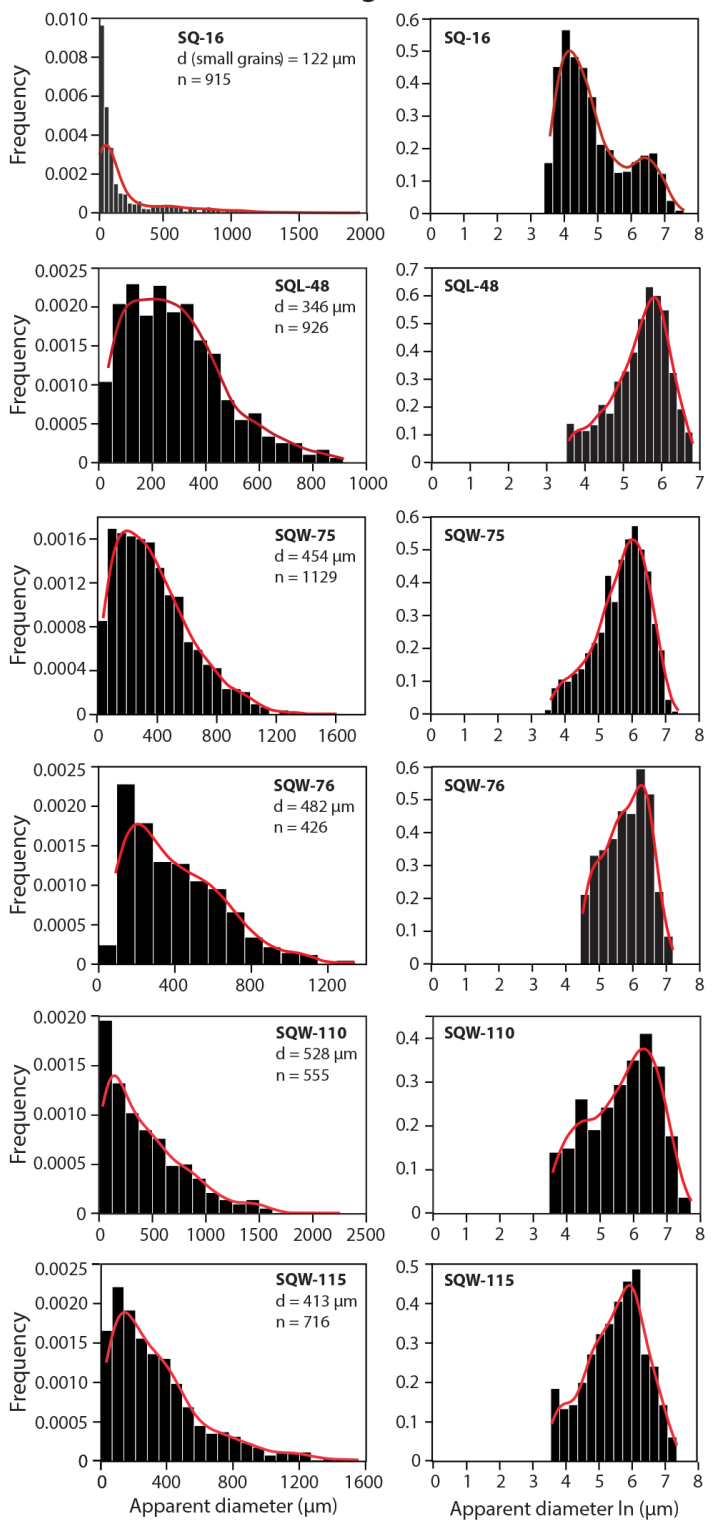

(b) Clinopyroxene
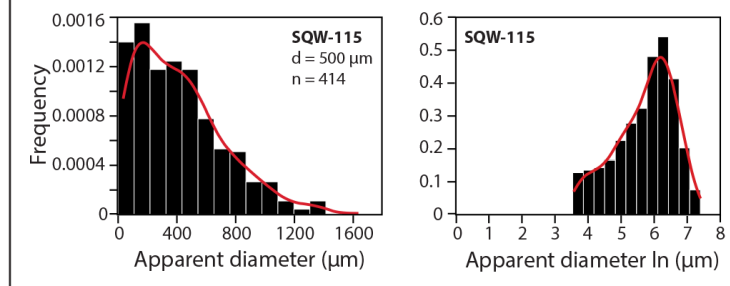

(c) Olivine
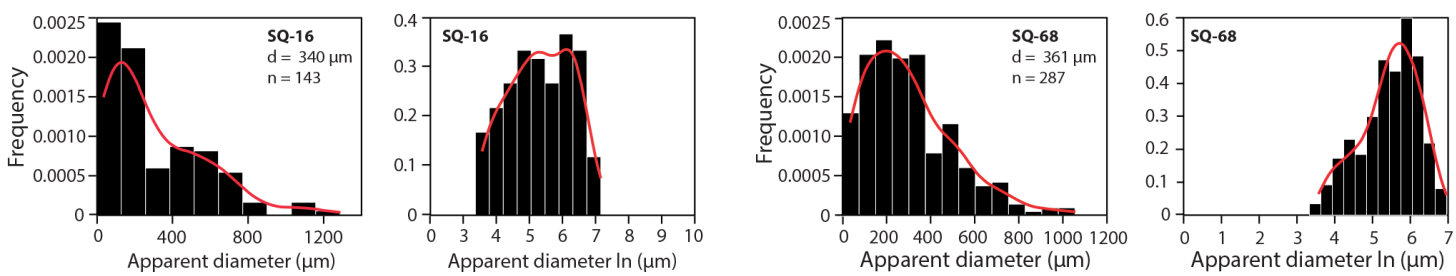

Figure 8. Recrystallized grain size distributions of (a) plagioclase, (b) clinopyroxene, and (c) olivine in granulites SQ-16, SQL-48, SQW-75, SQW-76, SQW-110, and SQW-115, as well as for lherzolite SQ-68. In each sample, plots show the number-weighted frequency distribution of the grain size (left) and the logarithmic grain size (right). Grain size is estimated with the equal circular diameter (ECD) method. The red lines show the Gaussian kernel density estimator. 
(a) Plagioclase
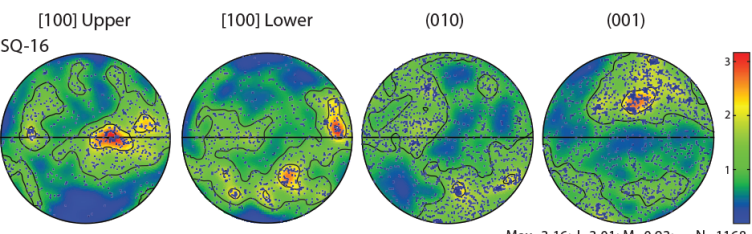

$\operatorname{Max}=3.16 ; \mathrm{J}=3.01 ; \mathrm{M}=0.03 ; \quad \mathrm{N}=1168$
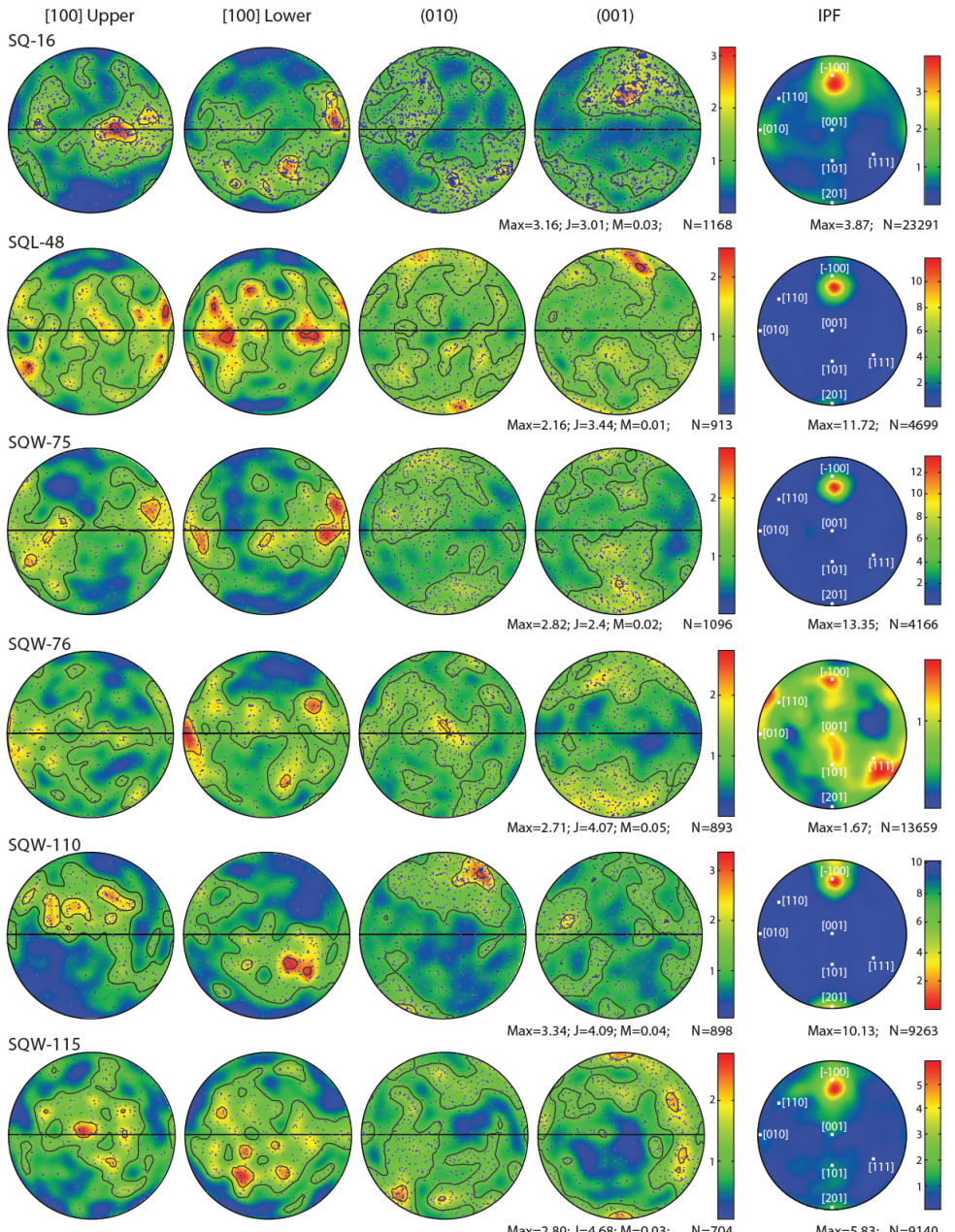

$\operatorname{Max}=3.87 ; \quad \mathrm{N}=23291$
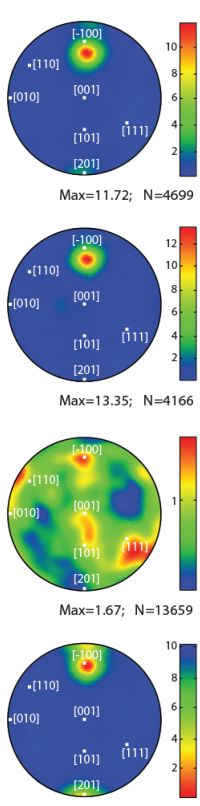

$\operatorname{Max}=10.13 ; \quad N=9263$

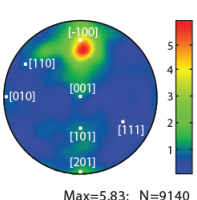

(b) Clinopyroxene
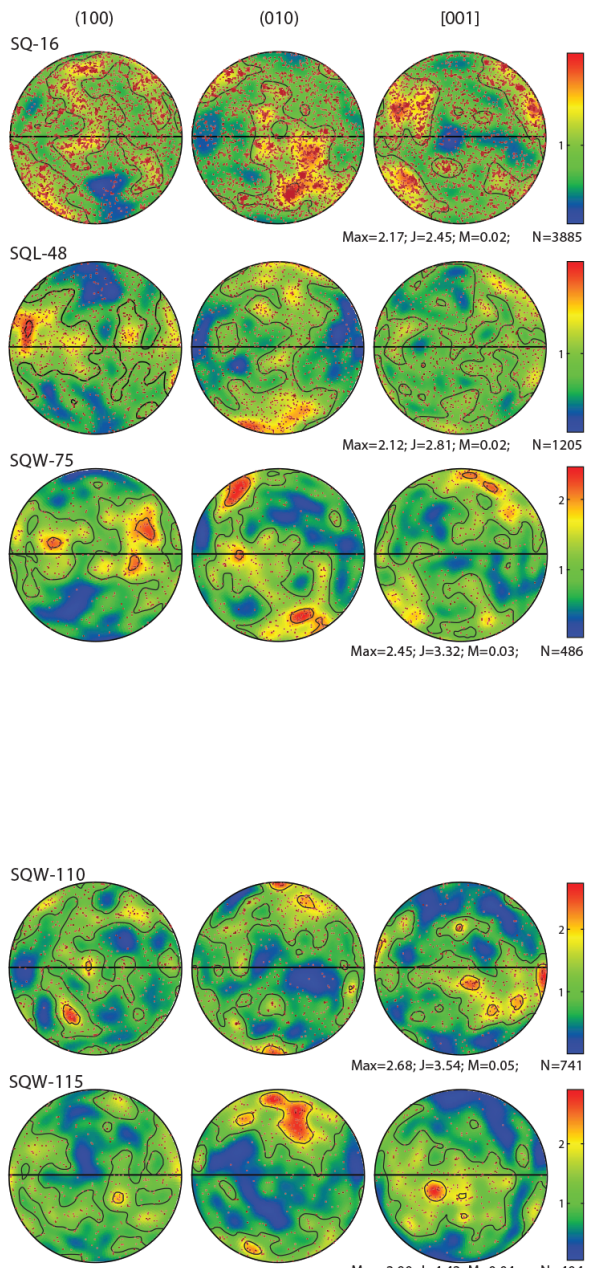

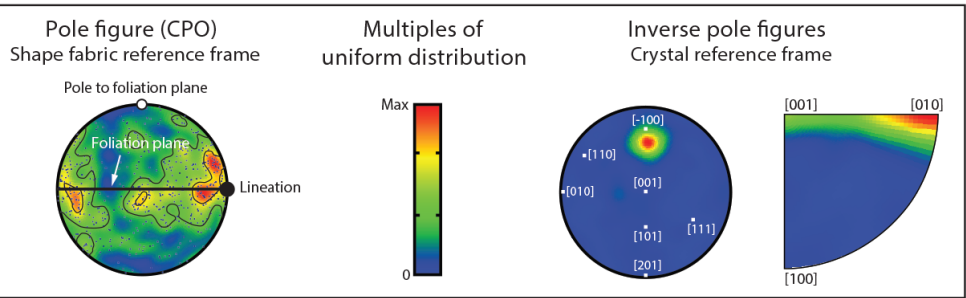

Figure 9.

mains is $163 \mu \mathrm{m}$. It is interesting to note the similarity in the recrystallized grain sizes and subgrain sizes - and therefore stresses - between the monophase olivine domains in the lherzolite and the olivine lens in the mafic granulite.

\subsection{Crystallographic preferred orientations}

We examined the bulk CPOs of plagioclase, clinopyroxene, orthopyroxene, and olivine in six granulites and one lherzolite (Fig. 9). In the granulites SQ-16, SQW-75, and SQW-110 and the lherzolite SQ-68, CPOs of plagioclase, clinopyrox- ene, and olivine monophase domains were analyzed, while in the granulites SQL-48, SQW-76, and SQW-115 CPOs were examined in polyphase domains. In one case (SQ-16), we analyzed the plagioclase and clinopyroxene CPOs in different monophase domains within the same thin section to explore the contribution of each domain to the bulk crystallographic texture (Fig. 10). In the following we use the convention that parentheses (hkl) indicate planes and square brackets [uvw] indicate axes. 
(c) Orthopyroxene
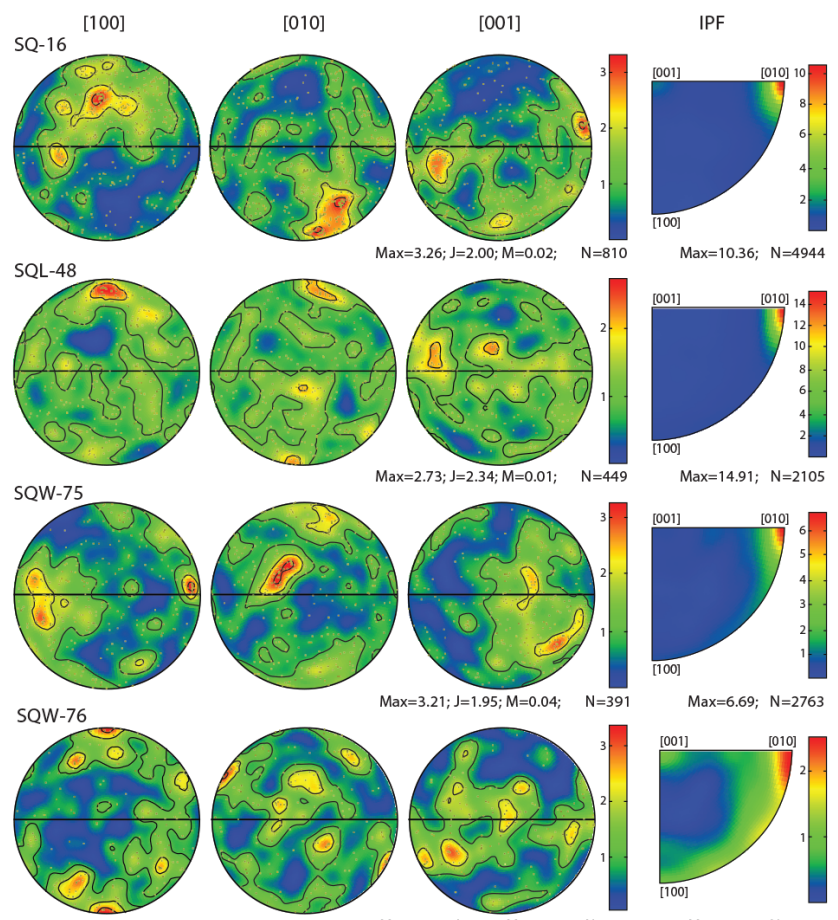

$\operatorname{Max}=3.21 ; J=1.95 ; M=0.04 ; \quad N=391$
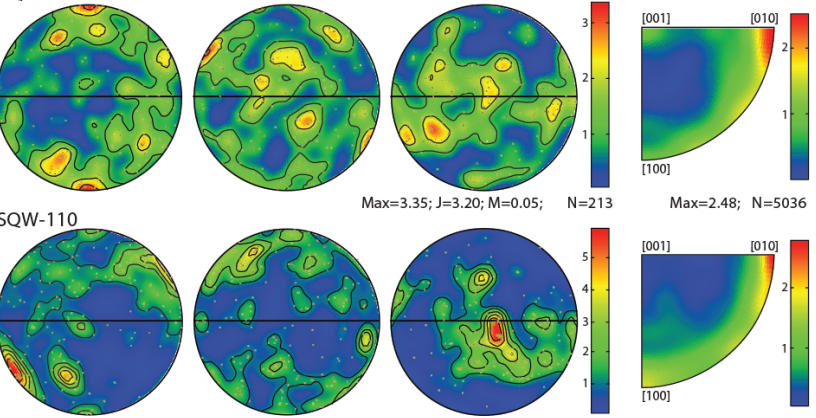

$\operatorname{Max}=3.35 ; \mathrm{J}=3.20 ; \mathrm{M}=0.05 ; \quad \mathrm{N}=213$

$\operatorname{Max}=2.48 ; \quad N=5036$
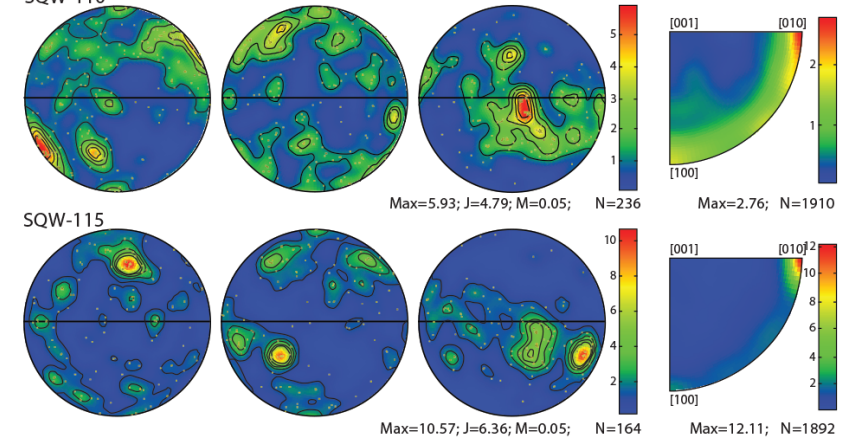

(d) Olivine
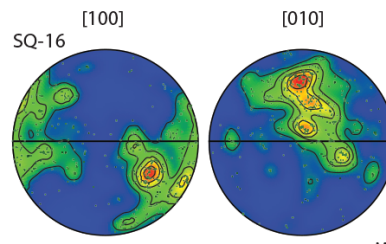

[001]

$\operatorname{Max}=12.11 ; \quad N=1892$
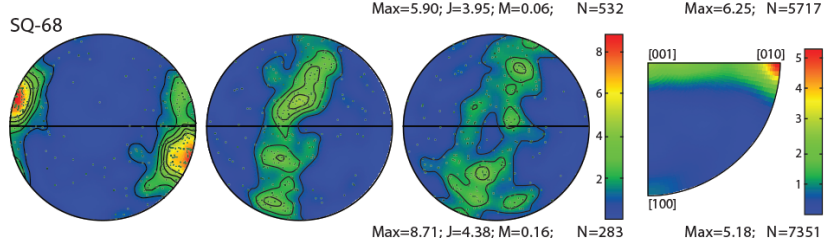

Figure 9. Equal area distributions of the crystallographic orientations and low-angle misorientations of (a) plagioclase, (b) clinopyroxene, (c) orthopyroxene, and (d) olivine grains. Crystallographic orientations are plotted as one point per grain data set in lower-hemisphere equalarea projections, relative to the observed foliation and lineation. Color scales are for multiples of uniform distribution. For each sample, the $J$ index, $M$ index, and the number of grains analyzed are given. Misorientation axes are from correlated misorientation angles between 2 and $10^{\circ}$. Inverse pole figures are in the crystallographic reference frame. 


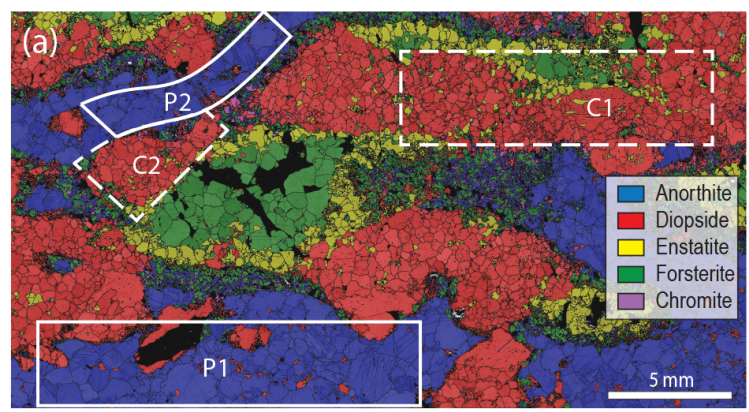

(b) Plagioclase

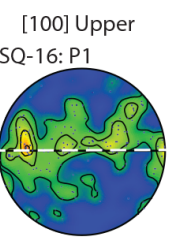

SQ-16: P2

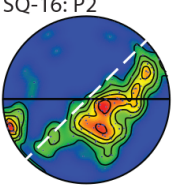

[100] Lower
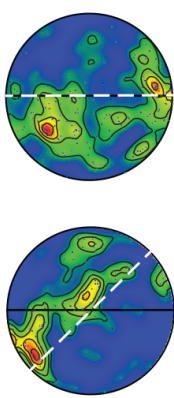

(010)

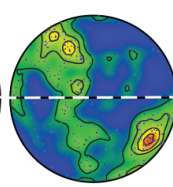

$\operatorname{Max}=4.85 ; \mathrm{J}=5.48 ; \quad \mathrm{N}=341$

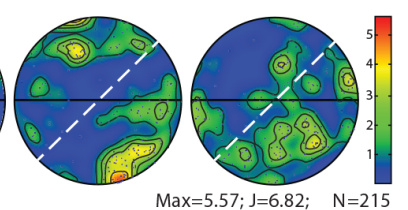

(c) Clinopyroxene

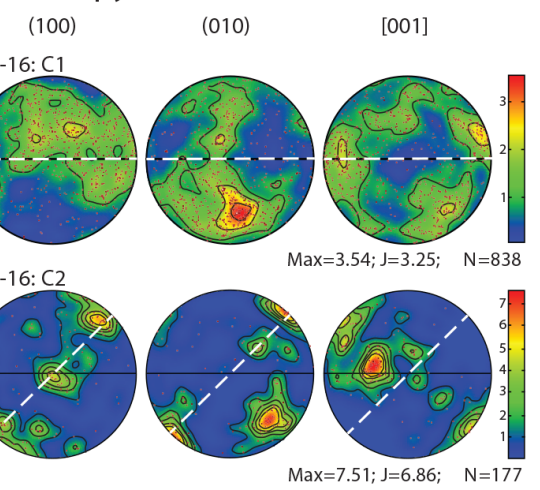

Figure 10. EBSD map and crystallographic orientations illustrating the control of the local flow field on plagioclase and clinopyroxene CPO. (a) Same EBSD map with Fig. 3a showing the location of the domains in which plagioclase and clinopyroxene domainal CPOs were analyzed. $(\mathbf{b}, \mathbf{c})$ Domainal plagioclase and clinopyroxene CPOs. Crystallographic orientations are plotted as one point per grain data set in lower-hemisphere equal-area projections, relative to the observed foliation and lineation. Color scales are for multiples of uniform distribution. For each sample, the $J$ index and the number of grains analyzed are given. White dashed lines describe the local shear plane. In $\mathrm{P} 2$ and $\mathrm{C} 2$ the shear plane is subparallel to the zone of localized shearing.

\subsubsection{Plagioclase}

Plagioclase has a weak to moderate CPO with $J$ and $M$ indices ranging from 2.4 to 4.7 and from 0.01 to 0.05 , respectively. The weak plagioclase CPO is exhibited by the distributions of the uncorrelated misorientation angles, which generally follow the theoretical random distribution (Fig. 11). From the observed plagioclase CPOs we may infer the active slip system(s), provided that dislocation creep is one of the deformation mechanisms contributing to the development of the CPO (see Sect. 5.2). In the San Quintín xenoliths, microstructures suggest that dislocation creep contributes to the development of plagioclase CPO; however, the low CPO strengths make the interpretation of slip systems tentative. Although there is significant variation and scatter in the CPOs, plagioclase crystallographic orientations in four xenoliths (SQ-16, SQL-48, SQW-75, and SQW-76) tend to show a maximum of [100] axes parallel or at a small angle to the lineation (Fig. 9a). The poles to the (010) and/or (001) planes tend to be grouped into maxima oriented at a high angle to the foliation (SQL-48, SQW-75, and SQW-76). The CPO observed in xenoliths SQ-16, SQL-48, SQW-75, and SQW-76 may indicate deformation accommodated by activation of the
(010)[100] and (001)[100] slip systems, which have been reported as primary plagioclase slip systems in naturally and experimentally deformed rocks (Ji et al., 1988, 2000, 2014; Xie et al., 2003; Gómez Barreiro et al., 2007; Mehl and Hirth, 2008; Hansen et al., 2013). One of the xenoliths (SQW-75) with a high concentration of [100] subparallel to the lineation is characterized by poles to (001) planes distributed along a girdle oriented at a high angle to the lineation (Fig. 9a). The poles to (010) planes are dispersed, leading to a more complex distribution. The plagioclase CPO in this xenolith may be classified as an axial-[100] type (axial-A CPO of Satsukawa et al., 2013). The axial-[100] CPO symmetry is consistent with the activation of the (010)[100] and (001)[100] plagioclase slip systems and may be associated with prolate shape fabric geometry (Satsukawa et al., 2013). Two xenoliths (SQW-110 and SQW-115) have poles to (010) and (001) planes at a high angle to the foliation and a small angle to the lineation, respectively (Fig. 9a). The [100] axes show concentrations within or close to the foliation plane and at a high angle to the lineation. This CPO pattern corresponds to the type-C plagioclase CPO of Ji et al. (2014), which is characteristic of plastically deformed mafic rocks. Type-C CPO indicates the dominance of the (010)[001] plagioclase slip 

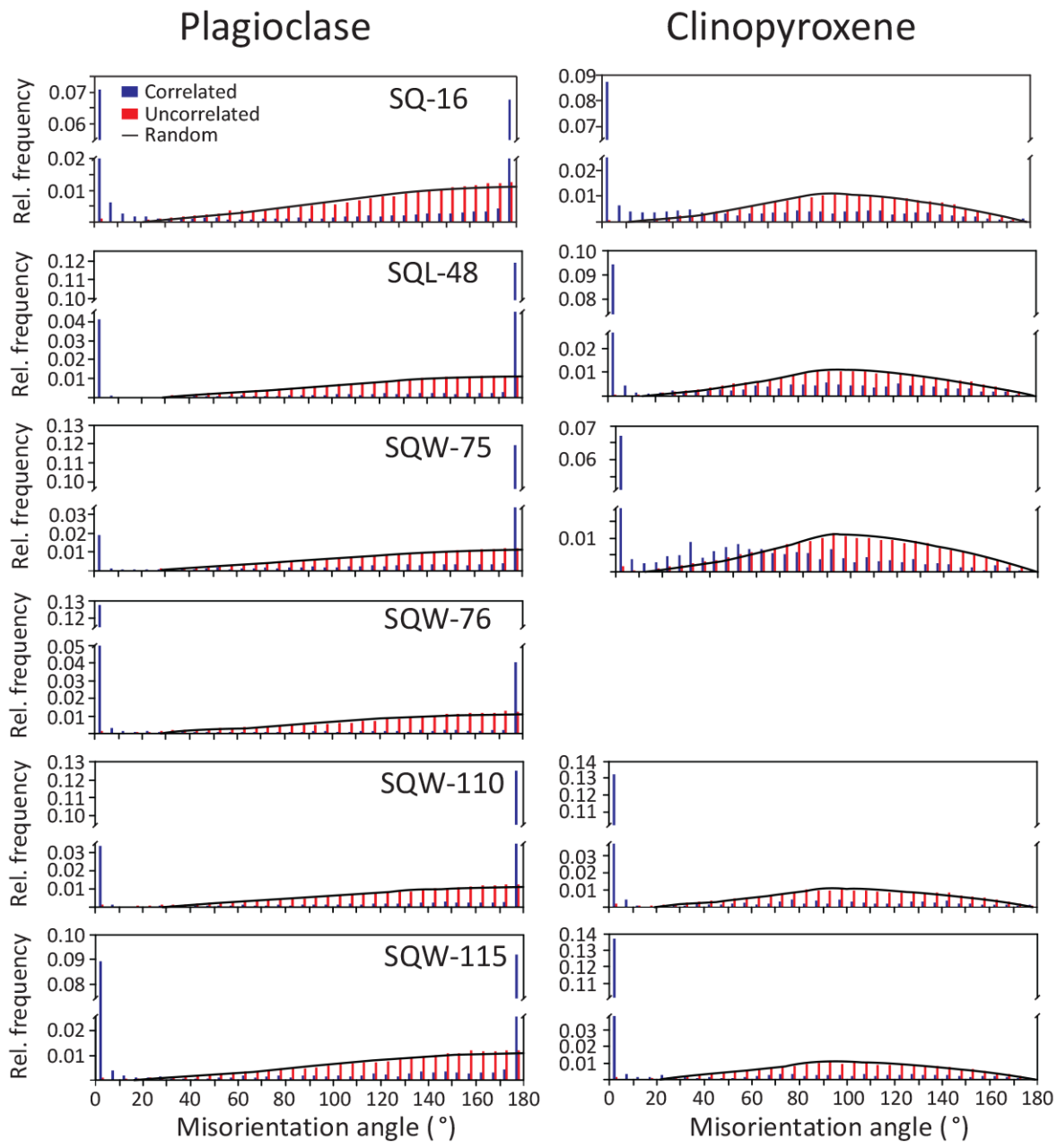

Olivine
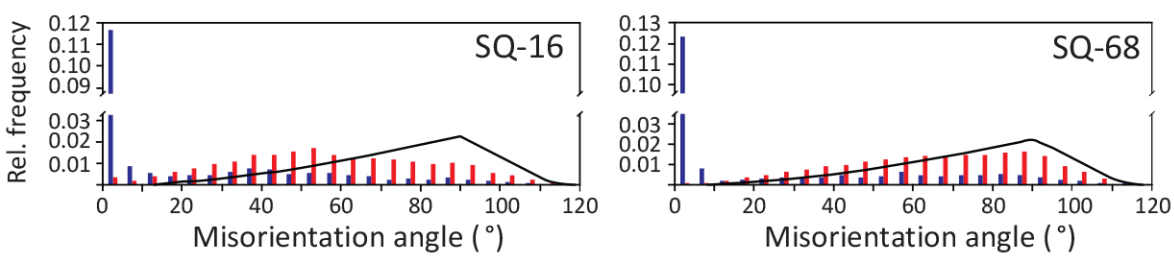

Figure 11. Histograms of misorientation angles for the correlated and uncorrelated distributions of plagioclase, clinopyroxene, and olivine.

system, which is commonly identified in naturally and experimentally deformed plagioclase (Ji et al., 1988; Kruse et al., 2001; Stünitz et al., 2003).

All granulite xenoliths show strong preferred orientations of low-angle $\left(2-10^{\circ}\right)$ misorientation axes, clustered subparallel to [100] axes (Fig. 9a). This observation is consistent with tilt subgrain boundaries in (010) built of (010)[001] edge dislocations. The correlated misorientation angle distributions are nonrandom and exhibit peaks at $<10^{\circ}$, which manifests the predominance of subgrain boundaries in plagioclase (Fig. 11). The second peak at $180^{\circ}$ represents twinning.

\subsubsection{Clinopyroxene}

Clinopyroxene $\mathrm{CPO}$ has low strength similar to the plagioclase CPO, with the $J$ and $M$ indices ranging from 2.5 to 4.4 and from 0.02 to 0.05 , respectively. The uncorrelated misorientation angle distributions largely follow the theoretical random distribution (Fig. 11). Clinopyroxene crystallographic orientations show a high concentration of the poles to the (010) plane at a low angle to the pole to foliation and a tendency of the poles to (100) planes or [001] axes to orient at low angles to the lineation (e.g., SQ-16, SQL-48, SQW110) (Fig. 9b). From the observed CPO patterns we may in- 
fer a possible activation of the (010)[100] and (010)[001] slip systems. Numerical simulations show that (010)[100] and (010)[001] are important slip systems for clinopyroxene CPO development (Ulrich and Mainprice, 2005). In xenolith SQL-48 the poles to the (010) plane form a girdle at a high angle to the lineation and [100] axes are subparallel to the lineation (Fig. 9b). This CPO pattern has an axially symmetric geometry and differs from the clinopyroxene L-type pattern (Helmstaedt et al., 1972; Ulrich and Mainprice, 2005) in that [100] axes instead of [001] axes are subparallel to the lineation.

\subsubsection{Orthopyroxene}

Orthopyroxene exhibits a weak to moderate $\mathrm{CPO}$, with the $J$ index ranging from 2.0 to 4.8 and the $M$ index ranging from 0.01 to 0.05 . The small number of grains $(<200)$ present in sample SQW-115 may have resulted in overestimation of the CPO strength for this xenolith $(J=6.4$, $M=0.05)$. Orthopyroxene shows a variety of CPO types in the analyzed granulites (Fig. 9c). In two samples (SQW-76 and SQW-115), the [100] axes are oriented at a high angle to the foliation plane and the [001] axes are oriented at a low angle to the lineation. This type of texture may indicate deformation with glide on the (100)[001] system and is frequently seen in naturally deformed orthopyroxene (Nicolas and Poirier, 1976; Vauchez et al., 2005; Jung et al., 2010; Soustelle et al., 2010). Xenoliths SQ-16 and SQW-110 show the [100] and/or [001] axis maxima oriented at a low angle to the lineation and the [010] maxima oriented at a high angle to the foliation (Fig. 9c). From the observed CPO patterns, we infer activation of the (010)[100] and (010)[001] slip systems. Glide on the (010)[001] slip system has been documented in naturally deformed orthopyroxene (Hidas et al., 2007; Jung et al., 2010), but alignment of [100] axes with the lineation is not commonly observed. Low-angle misorientation axes in orthopyroxene crystals are abundant and exhibit predominance of [010] rotation axes. This distribution of misorientation axes suggests subgrain boundaries predominantly built out of (100)[001] edge dislocations.

\subsubsection{Olivine}

We examined olivine CPO from a monomineralic lens in granulite xenolith SQ-16 and the upper-mantle lherzolite (Fig. 9d). Olivine in both the granulite and the lherzolite has a moderately strong CPO; the $J$ and $M$ indices are 4.0 and 0.06 in the granulite, respectively, while the olivine CPO in the lherzolite has a $J$ index of 4.4 and an $M$ index of 0.16 . Olivine in the granulite xenolith exhibits a CPO with [100] at a low angle to the lineation and both [010] and [001] at a high angle to the lineation (Fig. 9d). The [010] axes also show a high concentration within the foliation plane, at a high angle to the lineation. This distribution of olivine crystallographic orientations is intermediate between an A-type and E-type CPO pattern (Jung and Karato, 2001). The bulk olivine texture in the lherzolite xenolith SQ-68 has previously been described by Palasse et al. (2012; Fig. 4a). Olivine exhibits a strong CPO with a pattern intermediate between A-type and axial-[100]. Here, we focus on olivine CPO in the monophase domain from which we estimated the differential stress. Olivine crystallographic orientations exhibit an axial-[100] symmetry, characterized by point concentrations of [100] near the lineation and distributions of [010] and [001] axes along girdles at a high angle to the lineation (Fig. 9d). The axial-[100] CPO indicates activation of the $\{0 \mathrm{kl}\}$ [100] slip systems and may be associated with constrictional strain (Tommasi et al., 1999; Chatzaras et al., 2016) and high stress (Carter and Avé Lallemant, 1970; Jung and Karato, 2001).

In both xenoliths, low-angle misorientation axes show girdle distributions between [001] and [010] with a prominent maximum parallel to [010]. This distribution of misorientation axes is expected for subgrain boundaries built from $\{0 \mathrm{kl}\}$ [100] edge dislocations, with a predominant contribution of (001)[100] dislocations. It is striking that olivine misorientation axis distributions in the granulite and the lherzolite are similar, indicating that subgrain boundary formation was accommodated by dislocations with similar slip systems. The high proportion of low-angle $\left(<10^{\circ}\right)$ correlated misorientation angles in olivine of both granulite and lherzolite (Fig. 11) is consistent with the abundance of subgrain boundaries in both rocks.

\subsubsection{Domainal crystallographic preferred orientations}

The weak to moderate $\mathrm{CPO}$ of plagioclase and clinopyroxene could be the result of either consistently weak CPO throughout the analyzed samples or the combination of moderate to strong but variable CPOs in different parts of the samples. To distinguish between the two possibilities, we compared the plagioclase $(\mathrm{P})$ and clinopyroxene $(\mathrm{C}) \mathrm{CPO}$ patterns among different domains of xenolith SQ-16 (Fig. 10a). Domains P1, C1 and P2, C2 have their boundaries parallel and oblique $\left(\sim 45^{\circ}\right)$ to the main granulite foliation, respectively. The boundaries of domains $\mathrm{P} 2$ and $\mathrm{C} 2$ are parallel to the trace of a zone of localized shearing, which causes the displacement observed between the clinopyroxene domains $\mathrm{C} 1$ and $\mathrm{C} 2$.

We observe a strong correlation between the orientations of crystallographic axes and the orientations of the domain boundaries. Plagioclase in domain P1 tends to show an alignment of [100] axes within the foliation plane, with maxima subparallel to the lineation (Fig. 10b). Clinopyroxene in C1 also exhibits maxima of [001] axes and poles to (010) planes subparallel and at a high angle to the lineation, respectively (Fig. 10c). In domains $\mathrm{P} 2$ and $\mathrm{C} 2$, both minerals exhibit maxima of (010) planes and [100] axes parallel to the domain boundaries. The domainal CPOs of plagioclase ( $J$ index of 5.5 and 6.8) and clinopyroxene ( $J$ index of 3.3 and 6.9) are 
stronger compared to the bulk CPOs. Our observations indicate that the weak plagioclase and clinopyroxene bulk CPOs in granulite SQ-16 result from the combination of strong but inconsistent CPOs in different parts of the xenolith.

\section{Discussion}

\subsection{Tectonic context of the San Quintín xenoliths}

The constraints provided by the San Quintín xenoliths require careful interpretation because of the complex tectonic evolution of the Pacific-North American plate boundary. The basalts of the San Quintín volcanic field erupted recently (Pleistocene to less than 5000-6000 years ago), and the entrained peridotite xenoliths are interpreted to provide information for the "present" mechanical properties and composition of the upper mantle beneath the northwest part of the Baja California microplate (Cabanes and Mercier, 1988; Palasse et al., 2012). These studies attribute the strong deformation of the upper-mantle xenoliths to shearing along either a lithospheric-scale transcurrent shear zone or a subhorizontal shear zone in the shallow mantle, which decouples the deeper mantle from the lower crust of the Baja California microplate. In both cases, deformation in the upper-mantle xenoliths may be associated with the relative motion between the northern Baja California microplate and the Pacific plate (Plattner et al., 2007, 2009).

For the crustal xenoliths there is larger uncertainty regarding what time interval of the plate boundary deformation history they record and the crustal level they represent (Griffin and O'Reilly, 1987; Rudnick, 1992; Downes, 1993). Using the equilibration temperatures and pressures constrained from two-pyroxene geothermometry and phase equilibria modeling, respectively, we estimate metamorphic conditions in the range of $T=751 \pm 27-886 \pm 87^{\circ} \mathrm{C}$ and $P=400-560 \mathrm{MPa}$. We do not include the equilibration conditions estimated from the symplectite microdomain in SQ16 in this range. We distinguish two groups of equilibration temperatures; a low-temperature group ranging from 724 to $801^{\circ} \mathrm{C}$, and a high-temperature group ranging from 799 to $973^{\circ} \mathrm{C}$. The equilibration pressures from the San Quintín granulite xenoliths correspond to depths of $15-22 \mathrm{~km}$, i.e., to the uppermost lower crust.

Combining the microstructural information, geothermometry, and pseudosections, we propose the following $P-T$ evolution of the San Quintín granulite xenoliths. Gabbros were emplaced in the deep crust, possibly intruding and heating earlier metabasites that were metamorphosed to twopyroxene granulites. A first stage of cooling from high $T$ to $724-801{ }^{\circ} \mathrm{C}$ is manifested by the orthopyroxene rims around olivine, crystallization of melt pockets, and pyroxene exsolution. A second stage of cooling to $615-700^{\circ} \mathrm{C}$ is associated with decompression from $400-560 \mathrm{MPa}(15-22 \mathrm{~km})$ to 300 $370 \mathrm{MPa}(12-14 \mathrm{MPa})$, resulting in local symplectites. De- formation is likely to have operated at an early stage of the first cooling event, prior to the formation of the melt pockets. The symplectites and the fine-grained melt pockets are undeformed, in contrast to the orthopyroxene in the rims around olivine, which includes evidence of intragranular deformation.

We consider two possible end-member scenarios for the origin of the San Quintín crustal xenoliths. In the first scenario, the xenoliths formed in the shallow lower crust of the Mesozoic western Peninsular Ranges Batholith and were tectonically emplaced at shallower crustal levels prior to eruption and xenolith capture. In the second scenario, the xenoliths sample the uppermost lower crust in the active boundary between the Pacific plate and Baja California microplate.

In the first scenario, crustal and mantle xenoliths provide constraints for different snapshots of the plate boundary evolution. Granulites are interpreted to be associated with the Mesozoic Peninsular Ranges Batholith magmatic arc while the upper-mantle xenoliths are interpreted to record active processes beneath the Baja California peninsula. Equilibrium temperatures estimated from the granulite xenoliths are 200$300^{\circ} \mathrm{C}$ higher compared to the temperatures predicted from the maximum background geotherm for the magmatic arc (Rothstein and Manning, 2003) (dark blue curve in Fig. 12). This difference could be the result of transient heating during pluton emplacement (e.g., Barton et al., 1988). The granulites may have been tectonically emplaced at shallower crustal levels (i.e., middle or upper crust) soon after the cessation of their ductile deformation and prior to their entrainment. Prolonged residence of the xenoliths at high temperatures that characterize lower-crustal conditions would obliterate any intragranular deformation and dynamic recrystallization features such as subgrain boundaries, undulose extinction, and lobate grain boundaries observed in the analyzed xenoliths. Thus, in the first scenario, the gabbroic and granulite rocks resided in the upper crust before their entrainment. Gabbros are locally present in the western Peninsular Ranges Batholith; mafic plutonic rocks outcrop $20 \mathrm{~km}$ east of the San Quintín volcanic field (Gastil et al., 1975; Schmidt et al., 2014). It is therefore possible that the gabbroic xenoliths comprise entrained fragments of the western Peninsular Ranges Batholith. To the best of our knowledge, no exposures of rocks that experienced granulite-facies conditions are reported from the Baja California peninsula.

In the second scenario, both lower-crustal and uppermantle xenoliths record active processes in the boundary between the Pacific plate and the Baja California microplate. A geotherm of $40^{\circ} \mathrm{C} \mathrm{km}^{-1}$ fits well with the distribution of equilibrium conditions in the studied granulite xenoliths (broken red line in Fig. 12) and may describe the present geotherm beneath northwest Baja California. The studied granulites have a similar range of equilibrium temperatures as the porphyroclastic and mosaic uppermantle xenoliths (Cabanes and Mercier, 1988), implying near-isothermal conditions in the deeper lower crust beneath 


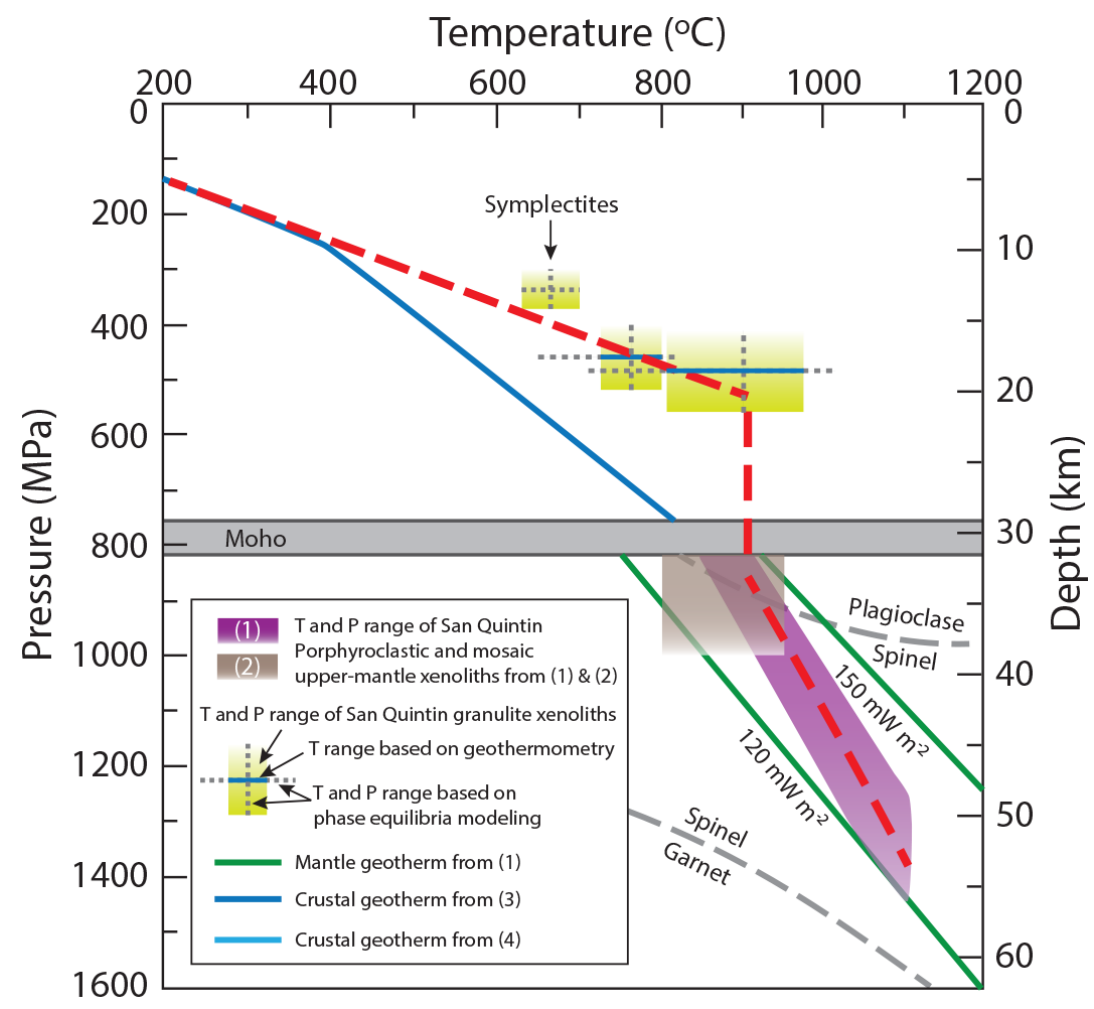

Figure 12. Estimated temperatures and pressures for the San Quintín xenoliths. The conditions for the lower-crustal xenoliths are from this study. The conditions for the upper-mantle xenoliths are from (1) Luhr and Aranda-Gómez (1997) and (2) Cabanes and Mercier (1988). Crustal geotherms are from (3) Rothstein and Manning (2003) and (4) Negrete-Aranda et al. (2013). Mantle geotherms are from (1) Luhr and Aranda-Gómez (1997) for surface heat flows of 120 and $150 \mathrm{~mW} \mathrm{~m}^{-2}$. The red line describes the inferred geotherm for the $P-T$ conditions in the San Quintín lower-crustal and upper-mantle xenoliths.

the San Quintín volcanic field (Fig. 12). The observed thermal structure of the lithosphere could correspond to a quasisteady-state geotherm reflecting long-lived plutonism (Depine et al., 2008). Important for the development of nearisothermal conditions in the crust are the existence of elevated heat fluxes from the mantle and melt focusing (Depine et al., 2008). Luhr et al. (1995) argued that partial melting occurs at unusually shallow mantle levels beneath the San Quintín volcanic field. High mantle heat flux leading to melting may be associated with the inferred slab window beneath the northern Baja California peninsula. The suggested location of the slab window correlates well with the location of the San Quintín volcanic field (Paulssen and De Vos, 2017). Focused asthenospheric upwelling within the slab window and strike-slip shearing in a lithospheric-scale transcurrent shear zone (e.g., the Baja California shear zone) can both result in melt focusing (e.g., Thorkelson and Breitsprecher, 2005; Cao and Neubauer, 2016). Thus, the interpretation of the granulite xenoliths as being derived from the modern uppermost lower crust beneath northwest Baja California is consistent with the active tectonic processes at the plate boundary.
The entrained crustal xenoliths, which range from undeformed gabbros to strongly deformed granulites, could define a horizontal strain gradient in the uppermost lower crust. In support of the existence of a horizontal strain gradient is the fact that gabbroic xenoliths are mainly present in the Media Luna volcanic complex while granulites are more common in the Woodward volcanic complex, with the two complexes being $3 \mathrm{~km}$ apart. Alternatively, the two volcanic complexes may sample different crustal levels. To explain the strongly deformed mosaic lherzolite xenoliths, as opposed to the less deformed coarse granular and porphyroclastic xenoliths, Cabanes and Mercier (1988) suggested the existence of a shear zone in the upper mantle beneath the San Quintín volcanic field. The upper-mantle xenolith (SQ-68) studied in this work has an equigranular mosaic microstructure (Palasse et al., 2012) and may sample this upper-mantle shear zone. We therefore suggest that the strongly deformed granulites and lherzolites entrained in the San Quintín basalts sample the uppermost lower-crust and upper-mantle sections of a lithospheric-scale wrench shear zone. Such a major shear zone could comprise a strand of the active Baja California shear zone, which accommodates the relative movement be- 
tween the Pacific plate and the Baja California microplate (Fig. 1).

Plagioclase and olivine CPOs provide further support of the interpretation that the San Quintín xenoliths may record active processes beneath the northwest Baja California microplate, as the fabrics are consistent with transtensional deformation. Plagioclase in the granulite xenolith SQW-75 and olivine in the lherzolite xenolith SQ-68 exhibit a CPO of axial-[100] symmetry (Fig. 9a, d). The axial-[100] CPO symmetry in both minerals was attributed to deformation producing prolate shape fabric geometries (Tomassi et al., 1999; Satsukawa et al., 2013; Chatzaras et al., 2016). Wrenchdominated transtension in Baja California (Legg et al., 1991; Umhoefer, 2011) could have induced constrictional strain in both the upper mantle and lower crust, leading to the formation of the observed axial-[100] CPO symmetries.

To summarize, the San Quintín granulite xenoliths formed at lithospheric depths corresponding to the uppermost lower crust. Ductile deformation of the granulites took place after cooling from the maximum $P-T$ conditions and prior to symplectite and melt formation. Deformation temperature and pressure conditions range from 720 to $970^{\circ} \mathrm{C}$ and from 400 to $560 \mathrm{MPa}$. The granulite xenoliths may sample either the Mesozoic Cordilleran magmatic arc or an active lithospheric-scale shear zone along the active Pacific-Baja California plate boundary. Although we cannot exclude the former, we consider the latter as the most likely tectonic scenario.

\subsection{Deformation mechanisms in the Baja California lithosphere}

We interpret the microstructures observed in the San Quintín granulite and lherzolite xenoliths to record deformation accommodated by a combination of dislocation creep and grain-size-sensitive creep. Activation of dislocation creep and grain boundary sliding was described in the San Quintín upper-mantle xenoliths (Palasse et al., 2012) and is further supported by our microstructural observations. Plagioclase and clinopyroxene, which are the major rock forming minerals in the studied granulites, also exhibit evidence for deformation by both grain-size-insensitive and grain-size-sensitive deformation mechanisms. Evidence for intragranular deformation by dislocation creep includes (1) phase segregation and formation of compositional layering (Kenkmann and Dresen, 2002); (2) undulose extinction of porphyroclasts; (3) a high number of low-angle $\left(<10^{\circ}\right)$ misorientation angles; (4) a large number of low-angle misorientation axes with strongly clustered distributions (Fliervoet et al., 1999); and (5) misorientation axes consistent with the orientations of tilt boundaries for known slip systems in plagioclase. Furthermore, dynamic recrystallization accommodated by subgrain rotation recrystallization is inferred from microstructures such as (1) recrystallized grains lacking significant internal deformation; (2) recrystallized grains with twins oriented at a low angle to the twins in adjacent porphyroclasts; and (3) core-and-mantle structures (e.g., Drury and Urai, 1990). Recrystallization, accommodated by grain boundary migration is inferred from interpenetrating grain boundaries (Drury and Urai, 1990). Thus, dislocation processes and dynamic recrystallization have contributed substantively to the total deformation of the mafic granulites.

Grain boundary sliding may have also been an important mechanism in the deformation of the lower-crustal xenoliths. Quadruple junctions associated with straight and aligned grain boundaries (Figs. 2e, f and 3c) comprise a transitional configuration of grain boundaries between two low energy, and therefore thermodynamically stable, triple junction configurations (Ashby and Verrall, 1973). This grain boundary readjustment is accommodated by translation of grains past each other by sliding along their boundaries. Boundaries of plagioclase grains aligned with twin boundaries (Fig. 3d) are interpreted as micro-shear zones (sensu Bons and Jessell, 1999), which preferentially localize shear along grain boundaries and intragranular easy slip planes. Deformation in micro-shear zones may cause localized movement of dislocations and development of subgrain boundaries near and subparallel to the grain boundaries, as observed within plagioclase grains in the San Quintín xenoliths (Fig. 3b) (Drury and Humphreys, 1988; Ree, 1994).

The San Quintín granulites are characterized by $120^{\circ}$ or nearly $120^{\circ}$ triple junctions between grains with limited intragranular deformation and straight, or smoothly curved, grain boundaries (Fig. 3c). This microstructure has been attributed to diffusion processes (e.g., Blenkinsop, 2000), which cause grain-boundary energy-driven grain growth and reorganization to low-energy triple junctions at hightemperature conditions (Gottstein and Shvindlerman, 2000; Piazolo et al., 2002). Such an interpretation is consistent with the high-temperature deformation estimated for the San Quintín granulite xenoliths.

The cooperation of grain-size-sensitive and grain-sizeinsensitive processes can also be inferred from the analysis of the CPOs and misorientation distributions. The weak to moderate bulk CPOs (Fig. 9), and the distributions of the uncorrelated misorientation angles, which follow the theoretical distribution for a random CPO (Fig. 11), indicate grain-size-sensitive creep. Conversely, the large number of low-angle misorientation axes and their nonrandom distributions (Fig. 11) imply deformation by dislocation creep. Further support for the latter argument comes from the detailed analysis of CPO in granulite SQ-16. In contrast to the bulk $\mathrm{CPO}$, the domainal CPOs are strong ( $J$ index 2 to 3 times higher compared to the bulk CPO) and variable among the different domains (Fig. 10). This observation implies that the weakness of the bulk CPO may not always be indicative of grain-size-sensitive processes. Rather, a weak $\mathrm{CPO}$ could be produced by the combination of strong domainal CPOs with 
variations in the topology of their crystallographic axis distributions.

The development of strong domainal CPOs can be attributed either to host control or to kinematic control. In the first case, a very strong CPO is inherited from a preexisting grain (e.g., porphyroclast) and is subsequently weakened due to transition in the dominant operating deformation mechanism from dislocation creep to a grain-size-sensitive deformation mechanism that involves grain boundary sliding (Kruse and Stünitz, 1999; Jiang et al., 2000; Skemer and Karato, 2008). In the second case, the CPO reflects the local flow field produced by flow heterogeneities (Bestmann et al., 2006; Mehl and Hirth, 2008). We argue that the CPOs formed in different domains of granulite SQ-16 are kinematically controlled and reflect the local flow field. Our interpretation is based on (1) the correlation between the concentrations of plagioclase and clinopyroxene crystallographic axes and the orientations of the local kinematic axes, e.g., foliation trace near the zone of localized shearing (domains P2 and $\mathrm{C} 2$ in Fig. 10) and (2) the back-rotation of the poles to (010) planes in plagioclase relative to the sense of shear on the zone of localized shearing (domain P2 in Fig. 10b). The sense of shear indicated by this back-rotation agrees with the displacement between the domains $\mathrm{C} 1$ and $\mathrm{C} 2$ along the zone of localized shearing. In agreement with the deformation experiments of Gómez Barreiro et al. (2007), the development of (010) maxima inclined against the shear sense and at high angles to the local shear plane is associated with dominant (010)[100] slip and subsidiary (010)[001] and (001)[100] slip. The activity of these slip systems is observed in the majority of the San Quintín granulite xenoliths. The (010)[100] and (010)[001] slips have been recognized as the primary slip systems in plagioclase at high-temperature deformation (Olsen and Kohlstedt, 1984; Ji and Mainprice, 1990; Stünitz et al., 2003; Mehl and Hirth, 2008). Thus, deformation in the granulite xenoliths involved dislocation glide on the easiest slip system(s).

To summarize, microstructural observations suggest that the mafic granulite and lherzolite xenoliths deformed by a combination of dislocation creep and grain-size-sensitive creep. A mechanism that has possibly contributed to deformation in the San Quintín xenoliths is dislocationaccommodated grain boundary sliding. This mechanism is increasingly recognized as an important deformation process in both plagioclase-rich rocks (Kruse and Stünitz, 1999; Kenkmann and Dresen, 2002; Svahnberg and Piazolo, 2010; Hansen et al., 2013; Miranda et al., 2016) and olivine-rich rocks (Hirth and Kohlstedt, 1995; Warren and Hirth, 2006; Drury et al., 2011; Hansen et al., 2011; Précigout and Hirth, 2014; Chatzaras et al., 2016). Although the large grain sizes in the San Quintín xenoliths imply that dislocation creep is the dominant deformation mechanism, transition to diffusion creep at grain sizes that are larger than expected is facilitated by the high homologous temperatures estimated in some of the mafic granulites.

\subsection{Strength of a strike-slip plate boundary}

The paleopiezometric methods used in this study to estimate differential stress are commonly interpreted to reflect steadystate creep (Twiss, 1977). Experimental deformation studies, however, show that microstructures may preserve information for transient deformation. Bimodal distributions of recrystallized grain sizes, such as those observed in SQ-16, have been attributed to a major stress increase (Kidder et al., 2016). The shear stress of $17 \mathrm{MPa}$ recorded by plagioclase in the San Quintín xenoliths (Fig. 13a) may thus correspond to a transient event of increased stress in the uppermost lower crust beneath northern Baja California. Assuming strike-slip deformation, shear stress is half of the differential stress estimated with recrystallized grain size paleopiezometry. Conversely, the partial foam and core-and-mantle-like microstructures observed in xenoliths SQW-75 and SQW110 are interpreted to form at decreasing stress conditions following a high-stress deformation event (Trepmann and Stöckhert, 2003; Druiventak et al., 2011; Kidder et al., 2016). The shear stress of $\sim 6 \mathrm{MPa}$ recorded in these two xenoliths may correspond to reducing stress conditions during postseismic relaxation following the event of increased stress. It is interesting that both the high-temperature and lowtemperature granulites record similarly low shear stresses. Thus, microstructural constraints from the San Quintín xenoliths support a shear stress decrease of at least $11 \mathrm{MPa}$ (corresponding decrease in differential stress of $21 \mathrm{MPa}$ ) between seismic slip and the post-seismic relaxation period in the seismically active boundary between the Pacific plate and Baja California microplate (Fig. 13a).

The deformation of increased stress leading to the bimodal distribution of plagioclase recrystallized grains could have occurred under decreasing metamorphic conditions. Clinopyroxene in xenolith SQ-16 also exhibits a bimodal grain size distribution. In this sample, however, we do not observe any correlation between equilibration temperature and the size of recrystallized clinopyroxene grains. Thus, we interpret the elevated stress levels in xenolith SQ-16 to be the result of stress increase under constant pressure and temperature conditions.

Another critical result from the San Quintín xenoliths is that shear stress in the upper mantle (9 MPa) is similar to the lower range of shear stresses in the uppermost lower crust $(\sim 6 \mathrm{MPa})$ (Fig. 13a). Olivine grains in the monophase area from which grain size was analyzed are characterized by a significant number of 120 or $\sim 120^{\circ}$ triple junctions, indicating a configuration transitional from partial foam to foam microstructure. We interpret the low stress in the upper-mantle xenolith to describe decreasing stress conditions in the upper mantle.

The stress recorded in the San Quintín upper-mantle xenolith is directly comparable to the cumulative range of differential stresses (10-18 MPa) estimated from upper-mantle xenoliths in the Coyote Lake volcanic field in the San An- 
(a) Shear stress (MPa)

(b)

Strain rate $\left(\mathrm{s}^{-1}\right)$

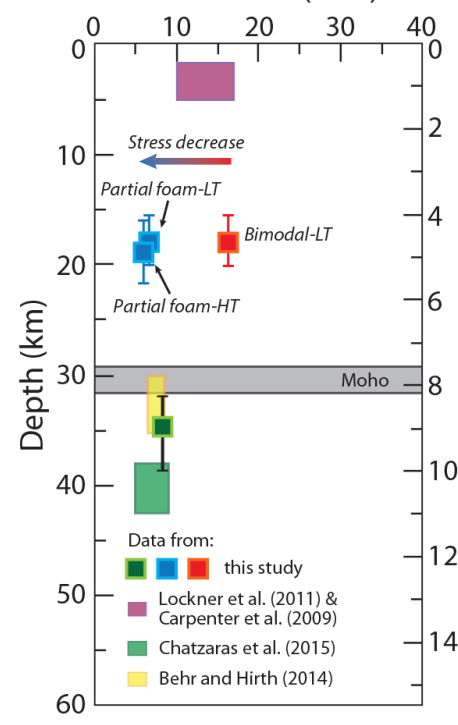

$10^{-19}$

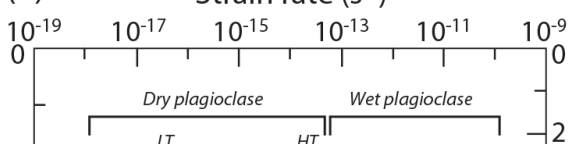

(c)

Viscosity (Pa.s)

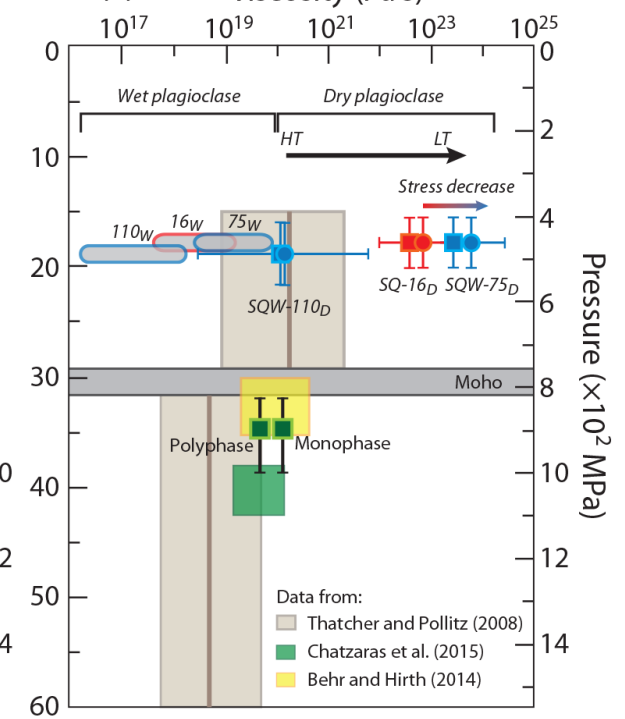

Figure 13. (a) Shear stress, (b) strain rate, and (c) viscosity as a function of depth for the San Quintín xenoliths. Error bars reflect the estimated uncertainties in pressure (vertical) and temperature (horizontal) conditions of deformation propagated to determine corresponding errors in stress, strain rate, and viscosity. Red symbols correspond to the xenolith with the bimodal grain size distribution, and blue symbols correspond to the xenoliths with the partial foam microstructure. The subscripts W and D next to the sample names describe whether a wet or a dry flow law was used. The Moho depth is from Paulssen and De Vos (2017). For explanation see text.

dreas fault system (Titus et al., 2007; Chatzaras et al., 2015) and the Cima volcanic field east of the eastern California shear zone (Behr and Hirth, 2014). Furthermore, shear stress in the uppermost lower crust beneath San Quintín is similar to the shear strength of the San Andreas fault (10-17 MPa) in the upper crust, constrained from frictional properties of the San Andreas Fault Observatory at Depth core samples (Lockner et al., 2011; Carpenter et al., 2012) (Fig. 13a).

The strength profile in Fig. 13a does not support a "jelly sandwich" or a "crème brûlée" model for the lithospheric strength of the strike-slip plate boundary. The jelly sandwich model requires a strong upper mantle, while the crème brûlée model assumes that crust comprises the load-bearing layer within the lithosphere (Brace and Kohlstedt, 1980; Chen and Molnar, 1983; Jackson, 2002; Burov and Watts, 2006). The observations from the Baja California shear zone, the San Andreas fault system, and the eastern California shear zone suggest that the shear stress of the upper crust, uppermost lower crust, and uppermost mantle in major strike-slip fault zones can be low (between 6 and $17 \mathrm{MPa}$ ) and approximately constant with depth. Plattner et al. (2009) suggest that a shear stress of $10 \mathrm{MPa}$ along the San Benito-Tosco-Abreojos fault, which is part of the Baja California shear zone, explains the observed geodetic motion of the Baja California microplate. This result further supports the suggestion for a low strength of the Pacific-Baja California plate boundary.

\subsection{Viscosity structure of a strike-slip plate boundary}

To describe the rheological structure of the boundary between the Pacific plate and the Baja California microplate, we quantify the rheological properties of the lithosphere beneath the San Quintín volcanic field combining microstructural constraints with laboratory-derived flow laws. Figure 13 describes the variation in strain rate and viscosity as a function of depth based on the xenolith constraints for the shallow lower crust and upper mantle. To calculate strain rate, we use the flow law:

$\dot{\varepsilon}=A \sigma^{n} d^{-m} \exp \left(\frac{-Q}{\mathrm{RT}}\right)$,

where $\dot{\varepsilon}$ is the strain rate, $A$ is a material constant, $\sigma$ is the differential stress, $n$ is the stress exponent, $d$ is the recrystallized grain size, $m$ is the grain size exponent, $Q$ is the activation energy, $R$ is the molar gas constant, and $T$ is the temperature. The term $A$ can be expanded to describe the dependence of strain rate on water fugacity. Because multiple deformation mechanisms operate simultaneously, we calculate the total strain rate as the sum of strain rates due to dislocation creep, diffusion creep, and dislocation-accommodated grain boundary sliding - the latter only for the upper mantle at the equilibration temperatures estimated for the xenoliths. The constitutive relationship describing the total strain rate can be written as

$\dot{\varepsilon}_{\text {total }}=\dot{\varepsilon}_{\text {dis }}+\dot{\varepsilon}_{\text {dif }}+\dot{\varepsilon}_{\text {disGBS }}$. 
Water content analysis shows that plagioclase in the mafic granulites is relatively dry. The presence of plagioclase grains in the mafic granulites with $\mathrm{H}_{2} \mathrm{O}$ content as high as $317 \mathrm{ppm}$ and of wet plagioclase in the felsic granulite, however, implies heterogeneous hydration in the lithosphere beneath northern Baja California. The composition of felsic granulite SQ-76 does not allow us to further assess the depths and conditions at which hydration took place. Dry olivine ( 0 $6.6 \mathrm{ppm} \mathrm{H}_{2} \mathrm{O}$ ) has been described in the upper-mantle xenoliths (Peslier and Luhr, 2006). Thus, to estimate strain rates, we use flow law parameters for dry and wet plagioclase, as well as for dry olivine.

For plagioclase, we use (1) the dislocation creep and diffusion creep flow law parameters for dry and wet anorthite from Rybacki and Dresen (2000) (RD00) and (2) the dislocation creep and diffusion creep flow law parameters for dry and wet An/25Di from Dimanov and Dresen (2005) (DD05). The DD05 flow law describes the rheology of plagioclase in synthetically produced two-phase (plagioclase and clinopyroxene) aggregates. In our analysis, we use flow law parameters appropriate for the modal composition of the San Quintín mafic granulites. In the diffusion creep flow laws (wet and dry) of DD05, the grain size component $d^{-m}$ is incorporated in the pre-exponential parameter $A$. However, plagioclase in the experiments of DD05 was significantly finer grained (mean grain size of $3.5 \mu \mathrm{m}$ ) compared to the plagioclase in the San Quintín granulite xenoliths (mean grain size of 122-528 $\mu \mathrm{m}$ ). To account for the difference in plagioclase grain size, we include the grain size term $\left(d^{-m}\right)$ as a variable in the flow law after recalculating the pre-exponential parameter $A$. Recalculation involved multiplication of $A$ with $3.5^{m}$, assuming a grain size exponent of $m=3$ for the grain-sizesensitive creep. The flow law parameters used in our strain rate calculations are presented in Table S5.

For dry olivine, we use the dislocation creep and diffusion creep flow laws from Hirth and Kohlstedt (2003), and for dislocation-accommodated grain boundary sliding we use the flow law from Hansen et al. (2011).

Combining the differential stress and strain rate estimates we calculate the effective viscosity $(\eta)$ using the relationship

$\eta=\frac{\sigma}{2 \dot{\varepsilon}}$.

For dry plagioclase, temperature is the main parameter controlling the rheology of the lower crust beneath northern Baja California. The lower temperature $\left(\sim 750^{\circ} \mathrm{C}\right)$ xenoliths, SQ-16 and SQW-75, are characterized by low strain rates, ranging from $9.8 \times 10^{-18}$ to $2.9 \times 10^{-16} \mathrm{~s}^{-1}$ (Fig. 13b), and high viscosities ranging from $5.7 \times 10^{22}$ to $6.8 \times 10^{23} \mathrm{~Pa} \cdot \mathrm{s}$ (Fig. 13c). Significantly higher strain rates of $4.5 \times 10^{-14}$ to $5.5 \times 10^{-14} \mathrm{~s}^{-1}$ and lower viscosities of $1.1 \times 10^{20}$ to $1.3 \times 10^{20} \mathrm{~Pa} \cdot \mathrm{s}$ are estimated for the higher temperature $\left(\sim 885^{\circ} \mathrm{C}\right)$ xenolith SQW-110. The difference in strain rate between xenoliths SQW-75 and SQW-110 of 4 orders of magnitude is due to the difference in the equilibration tem- peratures, given that both xenoliths record the same amount of stress. Note that the estimated strain rates in the lower crust should be considered as a minimum because the contribution of dislocation-accommodated grain boundary sliding to the total strain rate is not taken into account.

The slow strain rates $\left(10^{-18}-10^{-16} \mathrm{~s}^{-1}\right)$ estimated for the low temperature conditions could be representative for the intraplate deformation of the Baja California microplate (Plattner et al., 2007) rather than the deformation near the PacificBaja California plate boundary. Low strain rates are also in agreement with the presence of the undeformed gabbros in the San Quintín xenolith suite. However, it is difficult to explain the development of the strong foliation observed in the mafic granulites, which could indicate the existence of a shear zone at these low strain rates. Assuming that a shear strain $(\gamma)$ of 5 is needed to form a steady-state mylonitic microstructure (e.g., White et al., 1980), a period of $\sim 300 \mathrm{Myr}$ is required for the development of a strong foliation at a strain rate of $2.9 \times 10^{-16} \mathrm{~s}^{-1}$. Such a timeframe for lower-crustal deformation is unrealistic for a $\sim 30 \mathrm{Myr}$ time duration of the Pacific-North American plate boundary.

Two possible hypotheses, which could be related, are that foliation was formed during an earlier, high-temperature deformation event (see also Sect. 5.1) or that the estimated equilibration pressure and temperature underestimate the conditions at which deformation took place. In the former hypothesis, it is difficult to explain how the xenolith with the bimodal grain size distribution escaped grainboundary energy-driven grain growth at high-temperature conditions. The latter hypothesis is in agreement with the post-deformation decompression, which affected the two low-temperature xenoliths as suggested by the presence of symplectites and olivine as a secondary phase.

The presence of melt could cause strain weakening in the lower crust (e.g., Handy et al., 2001), and the presence of melt has also been suggested for the upper-mantle San Quintín xenoliths (Basu, 1977; Cabanes and Mercier, 1988; Luhr et al., 1995; Luhr and Aranda-Gómez, 1997; Palasse et al., 2012). The recrystallized plagioclase and clinopyroxene grains occurring either along the boundaries or within the junction areas of porphyroclasts could have initially crystallized from intergranular melt (e.g., Rosenberg and Berger, 2001). However, the presence of coreand-mantle structures and the occurrence of recrystallized grains with twins oriented at a low angle to the twins of adjacent porphyroclasts suggest that the recrystallized grains formed by subgrain rotation recrystallization of neighboring porphyroclasts. Nonetheless, we cannot exclude the presence of nanoscale grain boundary melt films (e.g., Drury and Fitz Gerald, 1996), which would induce melt-assisted grain boundary sliding (De Kloe et al., 2000; Holtzman et al., 2003; Tommasi et al., 2004; Palasse et al., 2012). The activation of the latter deformation mechanism would lead to an increase in strain rate. 
The water content in plagioclase may have been underestimated due to water loss during transport; hence, plagioclase in the mafic granulites could be wet rather than dry. The presence of wet plagioclase in the mafic granulites would be in accordance with the water-rich plagioclase in the felsic granulite. The strain rates, calculated using the wet RD00 and DD05 flow laws are 3 to 5 orders of magnitude higher compared to those calculated for the corresponding dry flow laws. Taking into account the uncertainty associated with the determination of the equilibration temperatures, strain rates range from $7.7 \times 10^{-14}$ to $2.0 \times 10^{-10} \mathrm{~s}^{-1}$ (Fig. 13b) and viscosities from $1.5 \times 10^{16}$ to $8.7 \times 10^{19} \mathrm{~Pa} \cdot \mathrm{s}$ (Fig. 13c).

The melt-present and water-present hypotheses examined above are not mutually exclusive, and further analyses are required in order to identify which of them better explains the apparent conflict between the microstructural observations and the strain rate calculations in the low-temperature xenoliths. For a dry lower crust, we consider the rheological constraints from the high-temperature xenolith as more robust. Thus, the critical result of our analysis is that the viscosity of the uppermost lower crust will be $\leq 10^{20} \mathrm{~Pa} \cdot \mathrm{s}$. This low viscosity could be the result of either high temperatures or increased water content in the lower crust. For the nearly isothermal conditions inferred for the lower crust beneath the San Quintín volcanic field (Fig. 12), viscosity will remain constant with depth. Because the dominant deformation mechanism in the northern Baja California lithosphere is transitional between dislocation creep and diffusion creep, any grain size reduction is not expected to result in a major change in strength or viscosity of the lower crust (De Bresser et al., 2001).

The estimated strain rate and viscosity of the upper mantle from our xenolith study is $1.4 \times 10^{-13} \mathrm{~s}^{-1}$ and $5.7 \times 10^{19} \mathrm{~Pa} \cdot \mathrm{s}$, respectively (Fig. 13b and c). To constrain the viscosity of the upper mantle we used the strain rate determined for the polyphase layers in the peridotite xenolith. Because clinopyroxene occurs at relatively small modal fractions $(\sim 7 \%)$ in the studied upper-mantle xenolith, and orthopyroxene behaves as a strong phase forming porphyroclasts, we used the viscosity of olivine as a reasonable approximation for the overall viscosity of the polyphase domains. The viscosity of the dry upper mantle estimated from the San Quintín xenoliths overlaps with the viscosities constrained from the San Andreas fault and Cima xenoliths (Behr and Hirth, 2014; Chatzaras et al., 2015) (Fig. 13c).

The viscosity of both the lower crust and upper mantle beneath northern Baja California is low $\left(\leq 10^{20} \mathrm{~Pa} \cdot \mathrm{s}\right)$. This argument is based on considering only the high-temperature (dry) plagioclase rheology and of wet plagioclase rheology as characterizing the lower crust. The viscosity of the upper mantle is less than 1 order of magnitude lower from the viscosity of a dry lower crust or corresponds to the high end of the viscosities of a wet lower crust. Thus, on a lithospheric scale, there is a weak lower crust overlying a less weak upper mantle. A rigid upper-mantle lid, which is essential for the jelly sandwich model for the lithospheric strength (Burov and Watts, 2006), is absent from the northern Baja California lithosphere (Palasse et al., 2012; this study). Rather, the weak lower-crustal layer beneath $\sim 18 \mathrm{~km}$ depth may comprise a large-scale flow zone, which acts to transfer the displacement field from the mantle to the upper crust (Teyssier and Tikoff, 1998).

\subsection{Implications for post-seismic transients in the lower crust}

The presence of a low-viscosity shear zone beneath the San Quintín volcanic field may exert significant control on postseismic deformation along the strike-slip plate boundary. The viscosities inferred from post-seismic relaxation studies likely reflect the rheology of the shear zone rather than the mechanical properties of the host rocks (Yamasaki et al., 2014). Thus, we would expect some overlap between the viscosities of the San Quintín xenoliths and those of the post-seismic relaxation studies. In Fig. 13c, we compare the lower-crust and upper-mantle viscosities constrained from xenoliths extracted along the Pacific-North America plate boundary (Behr and Hirth, 2014; Chatzaras et al., 2015; this study) with those constrained from post-seismic relaxation and post-glacial rebound studies for the western US (Thatcher and Pollitz, 2008). We consider the rheological constraints of the high-temperature San Quintín granulite xenolith as more representative for a dry lower crust beneath northern Baja California (see Sect. 5.4).

The viscosity of the dry lower crust $\left(\sim 10^{20} \mathrm{~Pa} \cdot \mathrm{s}\right)$, constrained from the high-temperature xenolith, is similar to the mean crustal viscosity of the relaxation studies (e.g., Thatcher and Pollitz, 2008). The partial foam microstructure in the xenolith is interpreted to form under decreasing stress conditions occurring during post-seismic transient deformation. Conversely, the viscosities $\left(10^{16}-10^{19} \mathrm{~Pa} \cdot \mathrm{s}\right)$ estimated for wet plagioclase in the granulites, are significantly lower or overlap with the low end of the crustal viscosities modeled from the post-seismic relaxation studies (Thatcher and Pollitz, 2008). This comparison shows that if deformation in the lower crust is accommodated by a combination of dislocation creep and grain-size-sensitive creep, the low-viscosity estimates from relaxation studies can be reconciled with either (1) a dry rheology at high deformation temperatures of $\sim 900^{\circ} \mathrm{C}$ or (2) a wet rheology. The combination of both elevated temperatures and hydration in the lower crust yields viscosities of $10^{16}-10^{17} \mathrm{~Pa} \cdot \mathrm{s}$, which are significantly lower compared to the crustal viscosities modeled from the relaxation studies. 


\section{Conclusions}

1. The San Quintín mafic granulite xenoliths have been extracted from the uppermost lower crust (15$22 \mathrm{~km}$ ) beneath northern Baja California, Mexico. The equilibration conditions $\left(T=750-890^{\circ} \mathrm{C}, P=400-\right.$ $-560 \mathrm{MPa})$ of the granulites indicate a hot geotherm of $40^{\circ} \mathrm{C} \mathrm{km}^{-1}$ for the upper $20 \mathrm{~km}$ of the crust. Nearly isothermal conditions in the deeper lower crust (20$30 \mathrm{~km}$ ) are inferred from the similarity of the equilibration temperatures between the lower-crustal and uppermantle xenoliths.

2. Deformation in both the uppermost lower crust and upper mantle is accommodated by a combination of dislocation creep and grain-size-sensitive creep.

3. The mafic granulites show two types of microstructural configuration. A bimodal grain size distribution is associated with the highest recorded differential stresses of $33 \mathrm{MPa}$ and is interpreted to form during a transient event of increased stress. Partial foam microstructure is associated with lower differential stresses of 12-13 MPa and is interpreted to form at decreasing stress conditions such as during post-seismic transients. A differential stress of $17 \mathrm{MPa}$ is estimated for the upper-mantle xenolith, which shows a partial foam to foam microstructure.

4. The lower crust is characterized by heterogeneous hydration. Plagioclase in the mafic granulites is relatively dry (7-317 ppm $\mathrm{H}_{2} \mathrm{O}$ ) and plagioclase in a felsic granulite is wet (151-4178 $\left.\mathrm{ppm} \mathrm{H}_{2} \mathrm{O}\right)$.

5. At high temperature and/or water content, the lower crust beneath northern Baja California is characterized by a low viscosity $\left(<10^{20} \mathrm{~Pa} \cdot \mathrm{s}\right)$. The presence of a lowviscosity zone in the lower crust may act to transfer the displacement field from the mantle to the upper crust, coupling the two lithospheric layers. The shallow upper mantle also has a low viscosity $\left(5.7 \times 10^{19} \mathrm{~Pa} \cdot \mathrm{s}\right)$, which indicates the lack of an upper-mantle lid beneath northern Baja California.

6. The upper mantle and the thermally weakened lower crust both exhibit equivalent low differential stress and viscosity during post-seismic transients in the Baja California shear zone.

Data availability. Please contact the corresponding author for access to the data used in this paper.

The Supplement related to this article is available online at https://doi.org/10.5194/se-8-1211-2017-supplement.
Competing interests. The authors declare that they have no conflict of interest.

Special issue statement. This article is part of the special issue "Analysis of deformation microstructures and mechanisms on all scales". It is a result of the EGU General Assembly 2016, Vienna, Austria, 17-22 April 2016.

Acknowledgements. Constructive comments from Scott Johnson, Luca Menegon, and the anonymous reviewer as well as editorial handling from Ilka Weikusat are highly appreciated. This research was supported by a Marie Curie International Outgoing Fellowship to Vasileios Chatzaras (PIOF-GA-2012-329183) within the 7th European Community Framework Programme. We thank Asish Basu (University of Texas, Arlington) for providing samples and suggesting xenolith localities. We acknowledge Saurabh Ghanekar for assistance in the field, Gill Pennock for her help with the EBSD analyses in the EM square facility at Utrecht University, Nick Roberts (University of Wisconsin-Madison) for discussions on the paper, Tilly Bouten (Utrecht University) and Hans de Groot (Naturalis Leiden) for assistance with the microprobe and SEM-EDS analyses, Peter van Krieken (Utrecht University) for assistance with the FTIR analyses, and Brian Hess (University of Wisconsin-Madison) for the production of high-quality thin sections used in EBSD analysis.

Edited by: Ilka Weikusat

Reviewed by: Luca Menegon, Scott Johnson, and one anonymous referee

\section{References}

Ashby, M. F. and Verrall, R. A.: Diffusion-accommodated flow and superplasticity, Acta Metall. Mater., 21, 149-163, 1973.

Atwater, T.: Plate tectonic history of the northeast Pacific and western North America, in: The eastern Pacific Ocean and Hawaii, edited by: Winterer, E. L., Hussong, D. M., and Dekker, R. W., Geological Society of America, Boulder, Colorado, N, 21-72, 1989.

Atwater, T. and Stock, J.: Pacific-North America plate tectonics of the Neogene southwestern United States: an update, Int. Geol. Rev., 40, 375-402, 1998.

Avé Lallemant, H. G.: Experimental deformation of diopside and websterite, Tectonophysics, 48, 1-27, 1978.

Barton, M. D., Battles, D. A., Debout, G. E., Capo, R. C., Christensen, J. N., Davis, S. R., and Trim, H. E.: Mesozoic contact metamorphism in the western United States, in: Metamorphism and crustal evolution of the western United States, edited by: Ernst, W. G., Pentice Hall, Los Angeles, California, Rubey, 7, 110-178, 1988.

Basu, A. R.: Hot spots, mantle plumes and a model for the origin of ultramafic xenoliths in alkali basalts, Earth Planet. Sc. Lett., 28, 261-274, 1975.

Basu, A. R.: Textures, microstructures and deformation of ultramafic xenoliths from San Quintin, Baja California, Tectonophysics, 43, 213-246, 1977. 
Behr, W. M. and Hirth, G.: Rheological properties of the mantle lid beneath the Mojave region in southern California, Earth Planet. Sc. Lett., 393, 60-72, 2014.

Bestmann, M., Prior, D. J., and Grasemann, B.: Characterisation of deformation and flow mechanics around porphyroclasts in a calcite marble ultramylonite by means of EBSD analysis, Tectonophysics, 413, 185-200, 2006.

Blenkisop, T. G.: Deformation Microstructures and Mechanisms in Minerals and Rocks, Springer, 2000.

Bons, P. D. and Jessell, M. W.: Micro-shear zones in experimentally deformed octachloropropane, J. Struct. Geol., 21, 323-334, 1999.

Brace, W. and Kohlstedt, D.: Limits on lithospheric stress imposed by laboratory experiments, J. Geophys. Res., 85, 6248-6252, 1980.

Brey, G. and Köhler, T.: Geothermobarometry in four-phase lherzolites II. New thermobarometers, and practical assessment of existing thermobarometers, J. Petrol., 31, 1353-1378, 1990.

Bunge, H.: Texture Analysis in Materials Science: Mathematical Models, Butterworths, London, 593 pp., 1982.

Burov, E. and Watts, A.: The long-term strength of continental lithosphere: "jelly sandwich" or "crème brûlée"?, GSA today, 16, 410, 2006.

Cabanes, N. and Mercier, J.: Insight into the upper mantle beneath an active extensional zone: the spinel-peridotite xenoliths from San Quintin (Baja California, Mexico), Contrib. Mineral. Petr., 100, 374-382, 1988.

Cao, S. and Neubauer, F.: Deep crustal expressions of exhumed strike-slip fault systems: Shear zone initiation on rheological boundaries, Earth-Sci. Rev., 162, 155-176, 2016.

Carpenter, B., Saffer, D., and Marone, C.: Frictional properties and sliding stability of the San Andreas fault from deep drill core, Geology, 40, 759-762, 2012.

Carter, N. L. and Avé Lallemant, H. G.: High temperature flow of dunite and peridotite, Geol. Soc. Am. Bull., 81, 2181-2202, 1970.

Chatzaras, V., Tikoff, B., Newman, J., Withers, A. C., and Drury, M. R.: Mantle strength of the San Andreas fault system and the role of mantle-crust feedbacks, Geology, 43, 891-894, 2015.

Chatzaras, V., Kruckenberg, S. C., Cohen, S. M., Medaris, L. G., Withers, A. C., and Bagley, B.: Axial-type olivine crystallographic preferred orientations: The effect of strain geometry on mantle texture, J. Geophys. Res.-Sol. Ea., 121, 4895-4922, 2016.

Chen, W. P. and Molnar, P.: Focal depths of intracontinental and intraplate earthquakes and their implications for the thermal and mechanical properties of the lithosphere, J. Geophys. Res., 88, 4183-4214, 1983.

Connolly, J. and Petrini, K.: An automated strategy for calculation of phase diagram sections and retrieval of rock properties as a function of physical conditions, J. Metamorph. Geol., 20, 697708, 2002.

De Bresser, J., Ter Heege, J., and Spiers, C.: Grain size reduction by dynamic recrystallization: can it result in major rheological weakening?, Int. J. Earth. Sci., 90, 28-45, 2001.

De Kloe, R., Drury, M. R., and Van Roermund, H. L. M.: Evidence for stable grain boundary melt films in experimentally deformed olivine-orthopyroxene rocks, Phys. Chem. Miner., 27(7), 480494, 2000.
DeMets, C.: A reappraisal of seafloor spreading lineations in the Gulf of California: Implications for the transfer of Baja California to the Pacific Plate and estimates of Pacific-North America motion, Geophys. Res. Lett., 22, 3545-3548, 1995.

Depine, G. V., Andronicos, C. L., and Phipps-Morgan, J.: Nearisothermal conditions in the middle and lower crust induced by melt migration, Nature, 452, 80-83, 2008.

Dickinson, W. R.: Tectonic implications of Cenozoic volcanism in coastal California, Geol. Soc. Am. Bull., 109, 936-954, 1997.

Dimanov, A. and Dresen, G.: Rheology of synthetic anorthite-diopside aggregates: Implications for ductile shear zone, J. Geophys. Res., 110, B07203, https://doi.org/10.1029/2004JB003431, 2005.

Dixon, T. H., Miller, M., Farina, F., Wang, H., and Johnson, D.: Present-day motion of the Sierra Nevada block and some tectonic implications for the Basin and Range province, North American Cordillera, Tectonics, 19, 1-24, 2000.

Dixon, T. H., Norabuena, E., and Hotaling, L.: Paleoseismology and Global Positioning System: Earthquake-cycle effects and geodetic versus geologic fault slip rates in the Eastern California shear zone, Geology, 31, 55-58, 2003.

Downes, H.: The nature of the lower continental crust of Europe: petrological and geochemical evidence from xenoliths, Phys. Earth Planet. In., 79, 195-218, 1993.

Druiventak, A., Trepmann, C. A., Renner, J., and Hanke, K.: Lowtemperature plasticity of olivine during high stress deformation of peridotite at lithospheric conditions - An experimental study, Earth Planet. Sc. Lett., 311, 199-211, 2011.

Drury, M. R. and Fitz Gerald, J. D.: Grain boundaries melt films in an experimentally deformed olivine-orthopyroxene rock: implications for melt distribution in upper mantle rocks, Geophys. Res. Lett., 23, 701-704, 1996.

Drury, M. R. and Humphreys, F. J.: Microstructural shear criteria associated with grain-boundary sliding during ductile deformation, J. Struct. Geol., 10, 83-89, 1988.

Drury, M. R. and Urai, J. L.: Deformation-related recrystallization processes, Tectonophysics, 172, 235-253, 1990.

Drury, M. R., Lallemant, H. A., Pennock, G. M., and Palasse, L. N.: Crystal preferred orientation in peridotite ultramylonites deformed by grain size sensitive creep, Étang de Lers, Pyrenees, France, J. Struct. Geol., 33, 1776-1789, 2011.

Fletcher, J. M. and Munguia, L.: Active continental rifting in southern Baja California, Mexico: Implications for plate motion partitioning and the transition to seafloor spreading in the Gulf of California, Tectonics, 19, 1107-1123, 2000.

Fletcher, J. M., Kohn, B. P., Foster, D. A., and Gleadow, A. J.: Heterogeneous Neogene cooling and exhumation of the Los Cabos block, southern Baja California: Evidence from fission-track thermochronology, Geology, 28, 107-110, 2000.

Fliervoet, T. F., Drury, M. R., and Chopra, P. N.: Crystallographic preferred orientations and misorientations in some olivine rocks deformed by diffusion or dislocation creep, Tectonophysics, 303, 1-27, 1999.

Freed, A. M. and Bürgmann, R.: Evidence of power-law flow in the Mojave desert mantle, Nature, 430, 548-551, 2004.

Gastil, R. G.: Plutonic zones in the Peninsular Ranges of southern California and northern Baja California, Geology, 3, 361-363, 1975. 
Gastil, R. G. and Miller, R. H.: The Prebatholithic Stratigraphy of Peninsular California, GSA Special Papers, 279, 7-27, 1993.

Gastil, R. G., Phillips, R. P., and Allison, E. C.: Reconnaissance geology of the state of Baja California, GSA Memoirs, 140, 1201, 1975.

Gómez Barreiro, J., Lonardelli, I., Wenk, H. R., Dresen, G., Rybacki, E., Ren, Y., and Tomeì, C. N.: Preferred orientation of anorthite deformed experimentally in Newtonian creep, Earth Planet. Sc. Lett., 264, 188-207, 2007.

Gottstein, G. and Shvindlerman, L. S.: Triple junction drag and grain growth in 2D polycrystals, Acta Mater., 50, 703-713, 2000.

Green, H. W. and Borch, R. S.: A new molten-salt cell for precision stress measurement at high-pressure, Eur. J. Mineral., 1, 213$219,1989$.

Griffin, W. and O'Reilly, S. Y.: Is the continental Moho the crustmantle boundary?, Geology, 15, 241-244, 1987.

Handy, M. R., Mulch, A., Rosenau, M., and Rosenberg, C. L.: The role of fault zones and melts as agents of weakening, hardening and differentiation of the continental crust: a synthesis, Geological Society, London, Special Publications, 186, 305-332, 2001.

Hansen, L. N., Zimmerman, M. E., and Kohlstedt, D. L.: Grain boundary sliding in San Carlos olivine: Flow law parameters and crystallographic-preferred orientation, J. Geophys. Res., 116, B08201, https://doi.org/10.1029/2011JB008220, 2011.

Hansen, L. N., Cheadle, M. J., John, B. E., Swapp, S. M., Dick, H. J., Tucholke, B. E., and Tivey, M. A.: Mylonitic deformation at the Kane oceanic core complex: Implications for the rheological behavior of oceanic detachment faults, Geochem. Geophy. Geosy., 14, 3085-3108, 2013.

Helmstaedt, H., Anderson, O. L., and Gavasci, A. T.: Petrofabric studies of eclogite, spinel-Websterite, and spinel-lherzolite Xenoliths from kimberlite-bearing breccia pipes in southeastern Utah and northeastern Arizona, J. Geophys. Res., 77, 4350-4365, 1972.

Hidas, K., Falus, G., Szabó, C., Szabó, P. J., Kovács, I., and Földes, T.: Geodynamic implications of flattened tabular equigranular textured peridotites from the Bakony-Balaton Highland Volcanic Field (Western Hungary), J. Geodyn., 43, 484-503, 2007.

Hirth, G. and Kohlstedt, D. L.: Experimental constraints on the dynamics of the partially molten upper mantle: Deformation in the diffusion creep regime, J. Geophys. Res., 100, 1981-2001, 1995.

Hirth, G. and Kohlstedt, D.: Rheology of the upper mantle and the mantle wedge: A view from the experimentalists, in: Inside the subduction Factory, edited by: Eiler, J., American Geophysical Union, Washington, D.C., 83-105, 2003.

Holland, T. and Powell, R.: An internally consistent thermodynamic data set for phases of petrological interest, J. Metamorph. Geol., 16, 309-343, 1998.

Holtzman, B. K., Kohlstedt, D. L., Zimmerman, M. E., Heidelbach, F., Hiraga, T., and Hustoft, J.: Melt segregation and strain partitioning: implications for seismic anisotropy and mantle flow, Science, 301, 1227-1230, 2003.

Jackson, J.: Strength of the continental lithosphere: time to abandon the jelly sandwich?, GSA today, 12, 4-9, 2002.

Ji, S. and Mainprice, D.: Recrystallization and fabric development in plagioclase, J. Geol., 98, 65-79, 1990.

Ji, S., Mainprice D., and Boudier, F.: Sense of shear in hightemperature movement zones from the fabric asymmetry of plagioclase feldspars, J. Struct. Geol., 10, 73-81, 1988.
Ji, S., Wirth, R., Rybacki, E., and Jiang, Z.: High-temperature plastic deformation of quartz-plagioclase multilayers by layernormal compression, J. Geophys. Res., 105, 16651-16664, 2000.

Ji, S., Shao, T., Salisbury, M. H., Sun, S., Michibayashi, K., Zhao, W., Long, C., Liang, F., and Satsukawa, T.: Plagioclase preferred orientation and induced seismic anisotropy in mafic igneous rocks, J. Geophys. Res.-Sol. Ea., 119, 8064-8088, https://doi.org/10.1002/2014JB011352, 2014.

Jiang, Z., Prior, D. J., and Wheeler, J.: Albite crystallographic preferred orientation and grain misorientation distribution in a lowgrade mylonite: implications for granular flow, J. Struct. Geol., 22, 1663-1674, 2000.

Johnson, E. A. and Rossman, G. R.: The concentration and speciation of hydrogen in feldspars using FTIR and 1H MAS NMR spectroscopy, Am. Mineral., 88, 901-911, 2003.

Johnson, S. E., Tate, M. C., and Fanning, C. M.: New geological and SHRIMP U- $\mathrm{Pb}$ zircon data in the Peninsular Ranges batholith, Baja California, México: Evidence for a suture?, Geology, 27, 743-746, 1999.

Jung, H. and Karato, S.: Water-induced fabric transitions in olivine, Science, 293, 1460-1463, https://doi.org/10.1126/science.1062235, 2001.

Jung, H., Park, M., Jung, S., and Lee, J.: Lattice preferred orientation, water content, and seismic anisotropy of orthopyroxene, J. Earth Sci., 21, 555-568, 2010.

Kenkmann, T. and Dresen, G.: Dislocation microstructure and phase distribution in a lower crustal shear zone-an example from the Ivrea-Zone, Italy, Int. J. Earth Sci., 91, 445-458, 2002.

Kidder, S., Hirth, G., Avouac, J.-P., and Behr, W.: The influence of stress history on the grain size and microstructure of experimentally deformed quartzite, J. Struct. Geol., 83, 194-206, 2016.

Kohlstedt, D. L., Evans, B., and Mackwell, S. J.: Strength of the lithosphere: Constraints imposed by laboratory experiments, J. Geophys. Res., 100, 17587-17602, 1995.

Kruse, R. and Stünitz, H.: Deformation mechanisms and phase distribution in mafic high temperature mylonites from the Jotun Nappe, Southern Norway, Tectonophysics, 303, 223-249, 1999.

Kruse, R., Stünitz, H., and Kunze, K.: Dynamic recrystallization processes in plagioclase porphyroclasts, J. Struct. Geol., 23, 1781-1802, 2001.

Langenheim, V. E. and Jachens, R. C.: Crustal structure of the Peninsular Ranges batholith from magnetic data: Implications for Gulf of California rifting, Geophys. Res. Lett., 30, 1597, https://doi.org/10.1029/2003GL017159, 2003.

Legg, M. R., Wong, V. O., and Suarez-Vidal, F.: Geologic structure and tectonics of the inner continental borderland of northern Baja California, in: The Gulf and Peninsular Province of the Californias, edited by: Dauphin, J. and Simoneit, B., American Association of Petroleum Geologists Memoir, 47, 145-177, 1991.

Lewis, J. L., Day, S. M., Magistrale, H., Castro, R. R., Rebollar, C., Astiz, L., Eakins, J., Vernon, F. L., and Brune, J. N.: Crustal thickness of the peninsular ranges and gulf extensional province in the Californias, J. Geophys. Res., 106, 13599-13611, 2001.

Lockner, D. A., Morrow, C., Moore, D., and Hickman, S.: Low strength of deep San Andreas fault gouge from SAFOD core, Nature, 472, 82-85, 2011.

Long, M. D.: Frequency-dependent shear wave splitting and heterogeneous anisotropic structure beneath the Gulf of California region, Phys. Earth Planet. In., 182, 59-72, 2010. 
Lopez-Sanchez, M. A. and Llana-Fúnez, S.: An evaluation of different measures of dynamically recrystallized grain size for paleopiezometry or paleowattometry studies, Solid Earth, 6, 475495, https://doi.org/10.5194/se-6-475-2015, 2015.

Luhr, J. F. and Aranda-Gómez, J. J.: Mexican peridotite xenoliths and tectonic terranes: correlations among vent location, texture, temperature, pressure, and oxygen fugacity, J. Petrol., 38, 10751112, 1997.

Luhr, J. F., Aranda-Gómez, J. J., and Housh, T. B.: San Quintín volcanic field, Baja California Norte, México: geology, petrology, and geochemistry, J. Geophys. Res., 100, 10353-10380, 1995.

Mehl, L. and Hirth, G.: Plagioclase preferred orientation in layered mylonites: Evaluation of flow laws for the lower crust, J. Geophys. Res., 113, B05202, https://doi.org/10.1029/2007JB005075, 2008.

Miranda, E. A., Hirth, G., and John, B. E.: Microstructural evidence for the transition from dislocation creep to dislocationaccommodated grain boundary sliding in naturally deformed plagioclase, J. Struct. Geol., 92, 30-45, 2016.

Mosenfelder, J. L., Rossman, G. R., and Johnson E. A.: Hydrous species in feldspars: A reassessment based on FTIR and SIMS, Am. Mineral., 100, 1209-1221, 2015.

Negrete-Aranda, R., Contreras, J., and Spelz, R. M.: Viscous dissipation, slab melting, and post-subduction volcanism in southcentral Baja California, Mexico, Geosphere, 9, 1714-1728, 2013.

Nicolas, A. and Poirier, J. P.: Crystalline Plasticity and Solid State Flow in Metamorphic Rocks, John Wiley \& Sons, London; New York, 1976.

Olsen, T. S. and Kohlstedt, D. L.: Analysis of dislocations in some naturally deformed plagioclase feldspars, Phys. Chem. Miner., 11, 153-160, 1984.

Palasse, L., Vissers, R., Paulssen, H., Basu, A., and Drury, M.: Microstructural and seismic properties of the upper mantle underneath a rifted continental terrane (Baja California): An example of sub-crustal mechanical asthenosphere?, Earth Planet. Sc. Lett., 345, 60-71, 2012.

Paulssen, H. and de Vos, D.: Slab remnants beneath the Baja California peninsula: Seismic constraints and tectonic implications, Tectonophysics, https://doi.org/10.1016/j.tecto.2016.09.021, 719-720, 27-36, 2017.

Peslier, A. H. and Luhr, J. F.: Hydrogen loss from olivines in mantle xenoliths from Simcoe (USA) and Mexico: Mafic alkalic magma ascent rates and water budget of the sub-continental lithosphere, Earth Planet. Sci. Lett., 242, 302-319, 2006.

Piazolo, S., Bons, P. D., Jessell, M. W., Evans, L., and Passchier, C. W.: Dominance of Microstructural Processes and Their Effect on Microstructural Development: Insights from Numerical Modelling of Dynamic Recrystallization, Geological Society, London, Special Publications, 200, 149-170, 2002.

Plattner, C., Malservisi, R., Dixon, T. H., LaFemina, P., Sella, G., Fletcher, J., and Suarez-Vidal, F.: New constraints on relative motion between the Pacific plate and Baja California microplate (Mexico) from GPS measurements, Geophys. J. Int., 170, 13731380, 2007.

Plattner, C., Malservisi, R., and Govers, R.: On the plate boundary forces that drive and resist Baja California motion, Geology, 37, 359-362, 2009.

Pollitz, F. F., Wicks, C., and Thatcher, W.: Mantle flow beneath a continental strike-slip fault: postseismic deformation after the 1999 Hector Mine earthquake, Science, 293, 1814-1818, https://doi.org/10.1126/science.1061361, 2001.

Précigout, J. and Hirth, G.: B-type olivine fabric induced by grain boundary sliding, Earth Planet. Sc. Lett., 395, 231-240, 2014.

Ree, J. H.: Grain boundary sliding and development of grain boundary openings in experimentally deformed octachloropropane, J. Struct. Geol., 16, 403-418, 1994.

Reyners, M., Eberhart-Phillips, D., and Stuart, G.: The role of fluids in lower-crustal earthquakes near continental rifts, Nature, 446, 1075-1078, https://doi.org/10.1038/nature05743, 2007.

Rogers, G., Saunders A., Terrell D., Verma S., and Marriner G.: Geochemistry of Holocene volcanic rocks associated with ridge subduction in Baja California, Mexico, Nature, 315, 389-392, 1985.

Rosenberg, C. L. and Berger, A.: Syntectonic Melt Pathways in Granitic Gneisses, and Melt-Induced Transitions in Deformation Mechanisms, Phys. Chem. Earth Pt. A, 26, 287-293, 2001.

Rothstein, D. A. and Manning, C. E.: Geothermal gradients in continental magmatic arcs: Constraints from the eastern Peninsular Ranges batholith, Baja California, México, in: Tectonic evolution of northwestern México and the southwestern USA, edited by: Johnson, S. E., Paterson, S. R., Fletcher, J. M., Girty, G. H., Kimbrough, D. L., and Martín-Barajas, A., Geological Society of America, Special Paper 374, 337-354, 2003.

Rudnick, R. L.: Xenoliths - samples of the lower continental crust, Continental lower crust, 23, 269-316, 1992.

Rybacki, E. and Dresen, G.: Dislocation and diffusion creep of synthetic anorthite aggregates, J. Geophys. Res., 105, 26017-26036, 2000.

Rybacki, E. M., Gottschalk, R. W., and Dresen, G.: Influence of water fugacity and activation volume on flow properties of finegrained anorthite aggregates, J. Geophys. Res., 111, B03203, https://doi.org/10.1029/2005JB003663, 2006.

Satsukawa, T., Ildefonse, B., Mainprice, D., Morales, L. F. G., Michibayashi, K., and Barou, F.: A database of plagioclase crystal preferred orientations (CPO) and microstructures implications for CPO origin, strength, symmetry and seismic anisotropy in gabbroic rocks, Solid Earth, 4, 511-542, https://doi.org/10.5194/se-4-511-2013, 2013.

Schmidt, K., Wetmore, P., Alsleben, H., and Paterson, S.: Mesozoic tectonic evolution of the southern Peninsular Ranges batholith, Baja California, Mexico: Long-lived history of a collisional segment in the Mesozoic Cordilleran arc, Geol. Soc. Am. Mem., 211, 645-668, 2014.

Silver, L. and Chappell, B.: The Peninsular Ranges Batholith: An insight into the evolution of the Cordilleran batholiths of southwestern North America, Earth Env. Sci. T. R. So., 79, 105$121,1988$.

Skemer, P. and Karato, S. I.: Sheared lherzolite xenoliths revisited, J. Geophys. Res-Sol. Ea., 113, B07205, https://doi.org/10.1029/2007JB005286, 2008.

Skemer, P., Katayama, I., Jiang, Z., and Karato, S.: The misorientation index: Development of a new method for calculating the strength of lattice-preferred orientation, Tectonophysics, 411, 157-167, 2005.

Soustelle, V., Tommasi, A., Demouchy, S., and Ionov, D.: Deformation and fluid-rock interaction in the supra-subduction mantle: microstructures and water contents in peridotite xenoliths from the Avacha Volcano, Kamchatka, J. Petrol., 51, 363-394, 2010. 
Spencer, J. E. and Normark, W. R.: Tosco-Abreojos fault zone: A Neogene transform plate boundary within the Pacific margin of southern Baja California, Mexico, Geology, 7, 554-557, 1979.

Stewart, E. D., Holyoke, C. D., and Kronenberg, A. K.: High pressure deformation experiments using solid confining media and Griggs piston-cylinder methods: Appraisal of stress and deformation in talc assemblies, Tectonophysics, 588, 171-178, 2013.

Stock, J. and Hodges, K.: Pre-Pliocene extension around the Gulf of California and the transfer of Baja California to the Pacific Plate, Tectonics, 8, 99-115, 1989.

Storey, M., Rogers, G., Saunders, A., and Terrell, D.: San Quintín volcanic field, Baja California, Mexico: "within-plate" magmatism following ridge subduction, Terra Nova, 1, 195-202, 1989.

Stünitz, H., Gerald, J. F., and Tullis, J.: Dislocation generation, slip systems, and dynamic recrystallization in experimentally deformed plagioclase single crystals, Tectonophysics, 372, 215233, 2003.

Svahnberg, H. and Piazolo, S.: The initiation of strain localisation in plagioclase-rich rocks: Insights from detailed microstructural analyses, J. Struct. Geol., 32, 1404-1416, 2010.

Tate, M. C. and Johnson, S. E.: Subvolcanic and deep-crustal tonalite genesis beneath the Méxican Peninsular Ranges, J. Geol., 108, 721-728, 2000.

Taylor, W.: An experimental test of some geothermometer and geobarometer formulations for upper mantle peridotites with application to the thermobarometry of fertile lherzolite and garnet websterite, Neues Jb. Miner.-Abh., 172, 381-408, 1998.

Teyssier, C. and Tikoff, B.: Strike-slip partitioned transpression of the San Andreas fault system: a lithospheric-scale approach, Geological Society, London, Special Publications, 135, 143-158, 1998.

Thatcher, W. and Pollitz, F. F.: Temporal evolution of continental lithospheric strength in actively deforming regions, GSA Today, 18, 4-11, 2008.

Thorkelson, D. J. and Breitsprecher, K.: Partial melting of slab window margins: genesis of adakitic and non-adakitic magmas, Lithos, 79, 25-41, 2005.

Titus, S. J., Medaris, L. G., Wang, H. F., and Tikoff, B.: Continuation of the San Andreas fault system into the upper mantle: evidence from spinel peridotite xenoliths in the Coyote Lake basalt, central California, Tectonophysics, 429, 1-20, 2007.

Todd, V. R., Erskine, B. G., and Morton, D. M.: Metamorphic and tectonic evolution of the Peninsular Ranges batholith, Englewood Cliffs, New Jersey, Prentice-Hall, 894-937, 1998.

Todd, V. R., Shaw, S. E., and Hammarstrom, J. M.: Cretaceous plutons of the Peninsular Ranges batholith, San Diego and westernmost Imperial counties, California: Intrusion across a Late Jurassic continental margin, Geological Society of America, Special paper, 374, 185-236, 2003.

Tommasi, A., Tikoff, B., and Vauchez, A.: Upper mantle tectonics: three-dimensional deformation, olivine crystallographic fabrics and seismic properties, Earth Planet. Sc. Lett., 168, 173-186, 1999.

Tommasi, A., Godard, M., Coromina, G., Dautria, J. M., and Barsczus, H.: Seismic anisotropy and compositionally induced velocity anomalies in the lithosphere above mantle plumes: a petrological and microstructural study of mantle xenoliths from French Polynesia, Earth Planet. Sc. Lett., 227, 539-556, 2004.
Toriumi, M.: Relation between dislocation density and subgrain size of naturally deformed olivine in peridotites, Contrib. Mineral. Petr., 68, 181-186, 1979.

Trepmann, C. A. and Stöckhert, B.: Quartz microstructures developed during non-steady state plastic flow at rapidly decaying stress and strain rate, J. Struct. Geol., 25, 2035-2051, 2003.

Twiss, R. J.: Theory and applicability of a recrystallized grain size paleopiezometer, in: Stress in the Earth Anonymous, Springer, 115, 227-244, 1977.

Ulrich, S. and Mainprice, D.: Does cation ordering in omphacite influence development of lattice-preferred orientation?, J. Struct. Geol., 27, 419-431, 2005.

Umhoefer, P. J.: Why did the Southern Gulf of California rupture so rapidly? - Oblique divergence across hot, weak lithosphere along a tectonically active margin, GSA Today, 21, 4-10, 2011.

Umhoefer, P. J. and Dorsey, R. J.: Translation of terranes: lessons from central Baja California, Mexico, Geology, 25, 1007-1010, 1997.

Underwood, E.: Quantitative Stereology, Addison-Wesley, Reading, Mass, 1970.

Valcke, S. L., Pennock, G. M., Drury, M. R., and De Bresser, J. H.: Electron backscattered diffraction as a tool to quantify subgrains in deformed calcite, Journal of Microscopy, 224, 264-276, 2006.

Van der Wal, D., Chopra, P., Drury, M., and Gerald, J. F.: Relationships between dynamically recrystallized grain size and deformation conditions in experimentally deformed olivine rocks, Geophys. Res. Lett., 20, 1479-1482, 1993.

Vauchez, A., Dineur, F., and Rudnick, R.: Microstructure, texture and seismic anisotropy of the lithospheric mantle above a mantle plume: insights from the Labait volcano xenoliths (Tanzania), Earth Planet. Sc. Lett., 232, 295-314, 2005.

Warren, J. M. and Hirth, G.: Grain size sensitive deformation mechanisms in naturally deformed peridotites, Earth Planet. Sc. Lett., 248, 438-450, 2006.

White, S. H., Burrows, S. E., Carreras, J., Shaw, N. D., and Humphreys, F. J.: On mylonites in ductile shear zones, J. Struct. Geol., 2, 175-187, 1980.

Wilks, K. R. and Carter, N. L.: Rheology of some continental lower crustal rocks, Tectonophysics, 182, 57-77, 1990.

Xie, Y., Wenk, H., and Matthies, S.: Plagioclase preferred orientation by TOF neutron diffraction and SEM-EBSD, Tectonophysics, 370, 269-286, 2003.

Yamasaki, T., Wright, T. J., and Houseman, G. A.: Weak ductile shear zone beneath a major strike-slip fault: Inferences from earthquake cycle model constrained by geodetic observations of the western North Anatolian Fault Zone, J. Geophys. Res.-Sol. Ea., 119, 3678-3699, 2014.

Zhang, X. and Paulssen, H.: Geodynamics of the Gulf of California from surface wave tomography, Phys. Earth Planet. In., 192-193, 59-67, 2012.

Zhang, X., Paulssen, H., Lebedev, S., and Meier, T.: 3D shear velocity structure beneath the Gulf of California from Rayleigh wave dispersion, Earth Planet. Sc. Lett., 279, 255-262, 2009. 